\title{
Carbon exchange between the atmosphere and subtropical forested cypress and pine wetlands
}

\author{
W. B. Shoemaker ${ }^{1}$, F. Anderson ${ }^{2}$, J. G. Barr ${ }^{3}$, S. L. Graham ${ }^{4}$, and D. B. Botkin ${ }^{5}$ \\ ${ }^{1}$ U.S. Geological Survey, Florida Water Science Center, 7500 SW 36th St, Davie, FL 33314, USA \\ ${ }^{2}$ U.S. Geological Survey, California Water Science Center, Placer Hall, 6000 J Street, Sacramento, CA, USA \\ ${ }^{3}$ South Florida Natural Resource Center, Everglades National Park, Homestead, FL 33030, USA \\ ${ }^{4}$ National Institute of Water and Atmospheric Research (NIWA), Christchurch, New Zealand \\ ${ }^{5}$ Department of Biology, University of Miami, Coral Gables, FL, USA
}

Correspondence to: W. B. Shoemaker (bshoemak@usgs.gov) and F. Anderson (fanders@usgs.gov)

Received: 30 September 2014 - Published in Biogeosciences Discuss.: 14 November 2014

Revised: 19 March 2015 - Accepted: 24 March 2015 - Published: 16 April 2015

\begin{abstract}
Carbon dioxide exchange between the atmosphere and forested subtropical wetlands is largely unknown. Here we report a first step in characterizing this atmosphericecosystem carbon $(\mathrm{C})$ exchange, for cypress strands and pine forests in the Greater Everglades of Florida as measured with eddy covariance methods at three locations (Cypress Swamp, Dwarf Cypress and Pine Upland) for 2 years. Links between water and $\mathrm{C}$ cycles are also examined at these three sites, as are methane emission measured only at the Dwarf Cypress site. Each forested wetland showed net $\mathrm{C}$ uptake from the atmosphere both monthly and annually, as indicated by the net ecosystem exchange (NEE) of carbon dioxide $\left(\mathrm{CO}_{2}\right)$. For this study, NEE is the difference between photosynthesis and respiration, with negative values representing uptake from the atmosphere that is retained in the ecosystem or transported laterally via overland flow (unmeasured for this study). Atmospheric $\mathrm{C}$ uptake (NEE) was greatest at the Cypress Swampp ( -900 to $-1000 \mathrm{~g} \mathrm{C} \mathrm{m}^{2} \mathrm{yr}^{-1}$ ), moderate at the Pine Upland ( -650 to $-700 \mathrm{~g} \mathrm{C} \mathrm{m}^{2} \mathrm{yr}^{-1}$ ) and least at the Dwarf Cypress ( -400 to $-450 \mathrm{~g} \mathrm{C} \mathrm{m}^{2} \mathrm{yr}^{-1}$ ). Changes in NEE were clearly a function of seasonality in solar insolation, air temperature and flooding, which suppressed heterotrophic soil respiration. We also note that changes in the satellite-derived enhanced vegetation index (EVI) served as a useful surrogate for changes in NEE at these forested wetland sites.
\end{abstract}

\section{Introduction}

On global scales, wetlands are generally considered sinks for atmospheric carbon dioxide (Troxler et al., 2013; Bridgham et al., 2006) and natural sources for methane emission (Whalen, 2005; Sjogersten et al., 2014). Wetlands in southern Florida's Greater Everglades (http://sofia.usgs.gov/) are expansive subtropical ecosystems that are carbon (C) accumulating over geologic timescales (Jones et al., 2014). Here we report a first step in characterizing modern rates of atmospheric-ecosystem carbon (C) exchange, for cypress strands and pine forests in the Greater Everglades of Florida.

In addition to the insight provided on the role of subtropical forested wetlands in the global carbon cycle, this research is expected to be useful for determining consequences of land-use changes in the Everglades region. Canal building and drainage projects in south Florida have reduced the original extent of the Everglades (Parker et al., 1955), decreased peat accretion rates and total carbon stocks, and reduced ecosystem services. Hohner and Dreschel (2015), for example, estimate that the Greater Everglades has less than $24 \%$ of its original peat volume and $19 \%$ of its original carbon. In response, state and federal governments are planning and executing complex projects to restore the Everglade's wetlands (http://www.evergladesrestoration.gov/) while concurrently avoiding flooding in urbanized areas and maintaining water supply.

Restoring ecosystems will affect water, energy and C cycles, as plants and soil processes adjust to changing wa- 
ter levels, salinities, nutrient loads and fire regimes. For example, Jimenez et al. (2012) and Schedlbauer et al. (2010) indicate that additional deliveries of water into peat and marl sawgrass wetlands may diminish $\mathrm{C}$ accumulation within these wetlands. Eddy-covariance-derived estimates of net ecosystem productivity declined with increasing inundation during the wet season (Jimenez et al., 2012; Schedlbauer et al., 2010). These results were partially attributed to the amount of vegetation that, due to flooding, could not directly exchange carbon dioxide with the atmosphere. The opposite trend was observed in a tidally influenced mangrove forest in the Everglades National Park. Lowered salinities, resulting from increased freshwater flow, resulted in increased daily PAR-use efficiency (i.e., the ratio of gross ecosystem productivity to photosynthetically active irradiance (PAR; Barr et al., 2010, 2012)). Also, ecosystem respiration losses were lower during periods of inundation (Barr et al., 2010, 2012), which increased net $\mathrm{C}$ uptake over the mangrove forest. These studies provide insights into water and $\mathrm{C}$ cycling over coastal sawgrass wetlands and mangrove forests. C cycling over other subtropical wetlands, such as cypress strands and pine forests, is largely unstudied (Sjogersten et al., 2014).

The primary goal of this paper is to quantify the magnitude and controls of $\mathrm{C}$ exchange within cypressand pine-forested wetlands. These wetland communities are defined by McPherson (1973), Duever et al. (1986) and Duever (2002). Quantities of interest include the net atmospheric-ecosystem C exchange (NEE), ecosystem respiration (RE), gross ecosystem exchange (GEE) and methane emissions. Latent heat flux (LE) and evapotranspiration (ET) are also quantified so that links between water and $\mathrm{C}$ cycles can be quantitatively studied. We address several specific objectives on daily, monthly and annual timescales, including (1) the magnitude of cypress- (tall and dwarf) and pineforested wetlands as net atmospheric $\mathrm{C}$ sources or sinks, (2) site differences in water and $\mathrm{C}$ exchange metrics (i.e., NEE, GEE, RE and surface energy fluxes), and (3) the magnitude of methane emission over a dwarf cypress wetland. Results from this study are expected to help define and predict responses of subtropical forested wetlands to regional (e.g., freshwater discharge) and global (e.g., air temperature) environmental change.

\section{Methods}

\subsection{Site description}

The study area is the Big Cypress National Preserve (BCNP) in southern Florida (Fig. 1). A variety of subtropical forested and non-forested wetland ecosystems are present in BCNP, including Pine Upland, Wet Prairie, Marsh, Hardwood Hammocks, Cypress Swamps, Dwarf Cypress and Mangrove Forests as formally characterized by McPherson (1973) and Duever et al. (1986, 2002). The distribution of ecosystems and plant communities in the BCNP is controlled by topography, hydrology, fire regimes and soil conditions (Duever et al., 1986). Marsh, Cypress Swamp, and Mangrove Forests typically occupy low elevations $(<2.5 \mathrm{~m}$ national geodetic vertical datum, NGVD-29), Wet Prairie occupies middle elevations ( 3 to $4 \mathrm{~m}$ NGVD-29), and Pine Uplands and Hardwood Hammocks occupy high elevations (>4 m NGVD29 ). These wetlands provide floodwater protection, hurricane buffering, substrate stabilization, sediment trapping, water filtration and other ecosystem services for urban areas and coastal estuaries.

Water and C fluxes were determined over Pine Upland, Cypress Swamp and Dwarf Cypress ecosystems (Fig. 1, Table 1) from December 2012 to November 2014 (Shoemaker et al., 2015d, e, f). The Pine Upland site (Fig. 2, Table 1), is classified as a mixed lowland pine site and is located in an extensive open-canopy pine forest with numerous smallto medium-sized cypress domes. The canopy is dominated by slash pine (Pinus elliottii) with an understory of saw palmetto (Serenoa repens), small trees and shrubs including holly (Ilex cassine), swamp bay (Persea palustris), myrsine (Myrsine cubana), wax myrtle (Myrica cerifera) and scattered sabal palms (Sabal palmetto) (Fig. 2). The ground cover is a diverse mix of short (less than $1 \mathrm{~m}$ high) grasses, sedges and forbs that are scattered in open-to-dense patches around the site. The open character of the site indicates regular burning with fire recurring every 5 years on average. Large cypress domes have a dense canopy of cypress but an open subcanopy and shrub strata, probably due to frequent fires. Substrates are primarily limestone bedrock, with sandy marl in the shallow depressions. Cypress domes in the area have a shallow organic substrate in the deeper areas.

The Cypress Swamp site (Fig. 2, Table 1) is classified as a swamp forest (Duever et al., 1986) and supports a tall, dense cypress forest with a subcanopy of mixed hardwoods (Fig. 2). Plant varieties include bald cypress (Taxodium distichum), holly, swamp bay, maple (Acer rubrum), an open-to-dense shrub layer with coco plum (Chrysobalanus icaco), myrsine, wax myrtle, an open-to-dense ground cover of swamp fern (Blechnum serrulatum), and a variety of grasses, sedges and forbs. The substrate is primarily topographically irregular limestone bedrock with organic accumulations in depressions in the rock.

The Dwarf Cypress site is classified as scrub cypress and is dominated by cypress, Taxodium distichum, and scattered (5 to $10 \%$ cover) sawgrass less than $1 \mathrm{~m}$ high (Fig. 2). Smallto medium-sized cypress domes are present, and periphyton is seasonally abundant (Fig. 2) from about July to December. The substrate is shallow marl overlying topographically irregular limestone bedrock.

\subsection{Carbon balance}

A mass balance equation can be used to conceptualize $\mathrm{C}$ fluxes. Net ecosystem C balance (NECB) is the amount of 


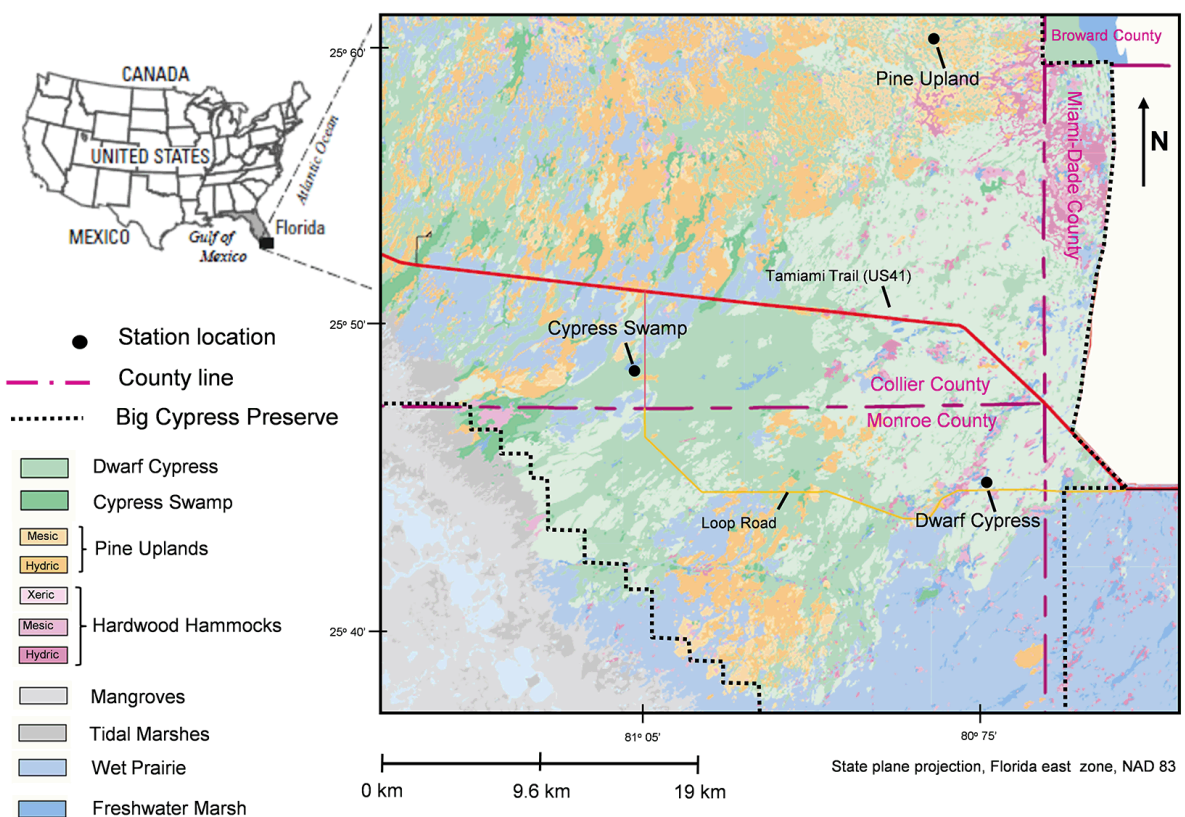

Figure 1. Location of the study area and vegetation communities, modified from Duever (2002).
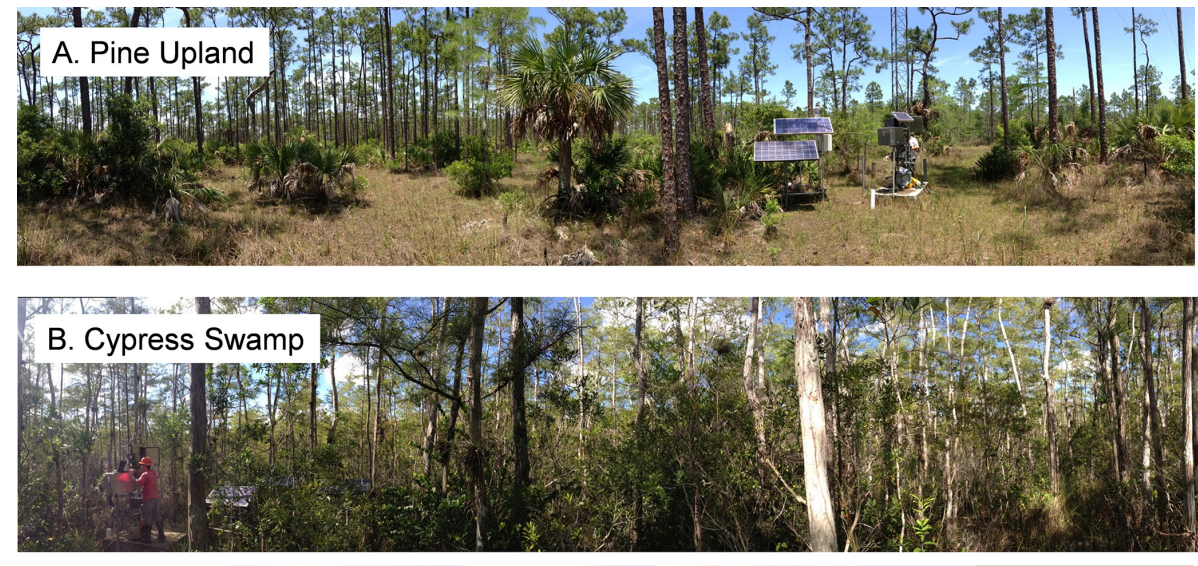

C. Dwarf Cypress

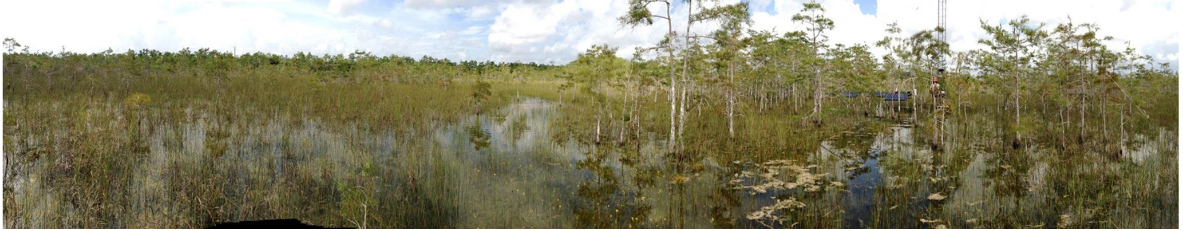

Figure 2. Panoramic photos of the (a) Pine Upland, (b) Cypress Swamp and (c) Dwarf Cypress plant communities.

$\mathrm{C}$ accumulating in the ecosystem, given in units of mass per area-time (Chapin et al., 2006; Troxler et al., 2013). NECB can be partly approximated using eddy covariance methods by measuring (1) the net vertical (one-dimensional) exchange of carbon dioxide (NEE) across the ecosystem-atmosphere interface, $(2)$ the net lateral flux $\left(F_{\text {net }}\right)$ of dissolved or particulate organic or inorganic $\mathrm{C}$ leaving the system and (3) the $\mathrm{C}$ released from methane emission $\left(F_{\mathrm{CH}_{4}}\right)$ :

$\mathrm{NECB}=-\mathrm{NEE}-F_{\text {net }}-F_{\mathrm{CH}_{4}}$.

A negative sign for NEE indicates a loss of carbon dioxide from the atmosphere. The net lateral flux of $\mathrm{C}\left(F_{\text {net }}\right)$ occurs primarily within surface water that flows down topographic gradients toward mangrove wetlands on the coast (Fig. 1). Technical difficulties inherent in measuring "sheet flow" and 
Table 1. Site locations, tower heights and summary of vegetation.

\begin{tabular}{lrrrrl}
\hline Site & Latitude & Longitude & $\begin{array}{r}\text { Height of } \\
\text { tower }(\mathrm{m})\end{array}$ & $\begin{array}{r}\text { Height of } \\
\text { vegetation (m) }\end{array}$ & Vegetation \\
\hline Dwarf Cypress & 25.7624 & -80.8934 & 16.8 & 0.5 to 10 & Small cypress and sawgrass \\
Cypress Swamp & 25.8265 & -81.1020 & 38.1 & 0.5 to 21 & Tall cypress \\
Pine Upland & 26.0004 & -80.9260 & 38.1 & 0.5 to 21 & Pine, sawgrass and cypress \\
\hline
\end{tabular}

the dissolved or particulate organic or inorganic C concentrations within surface water did not allow the quantification of this term. Therefore, we only report exchanges of gases between the atmosphere and the ecosystem. Methane emission $\left(F_{\mathrm{CH}_{4}}\right)$ at the Dwarf Cypress site was determined using an LI-7700 open-path methane analyzer (Shoemaker et al., 2015d). The cost of the methane analyzer and safety issues related to climbing tall towers limited the measurements of $F_{\mathrm{CH}_{4}}$ to a single site (Dwarf Cypress, Fig. 2). Thus, our daily and annual NEE estimates likely are an upper bound for $\mathrm{C}$ accumulation at the Pine Upland and Cypress Swamp sites (and a lower bound for atmospheric transfer to the ecosystem) due to uncertainty associated with methane emission and lateral C fluxes.

\subsection{Eddy covariance method and gap filling}

The eddy covariance method (Dyer, 1961; Tanner and Greene, 1989) is a one-dimensional (vertical) approach for measuring the exchange of gases within the atmospheric surface layer (Campbell and Norman, 1998). Key instrumentation (Table 2) includes sonic anemometers that rapidly $(10 \mathrm{~Hz})$ measure wind velocity and gas analyzers that rapidly measure gas concentrations (Table 2) in the atmosphere. The covariance between vertical wind velocities and gas concentrations determines the net exchange of gases between the ecosystem and the atmosphere. Additional instrumentation (Table 2) was installed at each site to measure net radiation, soil-heat flux, soil temperatures, air temperature and relative humidity, and the distance of water above or below land surface (using pressure transducers). Pressure transducers were placed at the bottom of groundwater wells to measure the distance of water above and below land surface. Pressure transducers were corrected monthly for instrumentation drift using manual depth-to-water measurements from the top of the well casings. The manual depth-to-water measurements allowed the precise calibration of continuous water distance above or below land surface. Monthly site visits were made to download data, perform sensor inspections and complete other site maintenance. All instrumentation was visually inspected, leveled, cleaned or replaced as necessary.

Raw, $10 \mathrm{~Hz}$, vertical wind speed, temperature and gas concentration data were processed to half-hourly fluxes using EddyPro software (version 4.0.0) following advanced protocols that included random uncertainty estimates (Finkelstein and Sims, 2001), spiking filters, double coordinate rota- tions, blocked-average detrending, statistical filters, air density and oxygen corrections (Tanner and Thurtell, 1969; Baldocchi et al., 1988; Webb et al., 1980; Tanner et al., 1993), and high-pass filtering. Processed data yielded half-hourly mean values of NEE, methane, and sensible and latent heat fluxes that were filtered to remove periods with unrealistic fluxes (Cypress Swamp - latent heat fluxes $>800$ and $<-100$ watts $\mathrm{m}^{-2}$, sensible heat flux $>500$ and $<-150$, NEE $>25$ and $<-30 \mu \mathrm{mol} \mathrm{m}^{-2} \mathrm{~s}^{-1}$; Dwarf Cypress - latent heat fluxes $>600$ and $<-150$ watts $\mathrm{m}^{-2}$, sensible heat flux $>500$ and $<-100$, NEE $>20$ and $<-25 \mu \mathrm{mol} \mathrm{m}^{-2} \mathrm{~s}^{-1}$, FCH4 $>0.5$ and $<-0.2$; Pine Upland - latent heat fluxes $>1000$ and $<-$ 300 watts $\mathrm{m}^{-2}$, sensible heat $>500$ and $<-200$ watts $\mathrm{m}^{-2}$, NEE $>125$ and $<-100 \mu \mathrm{mol} \mathrm{m}^{-2} \mathrm{~s}^{-1}$ ). These thresholds may inherently disregard some naturally large uptake or efflux events. For instance, ebullition events can be an important mechanism for the episodic release of methane to the atmosphere (Comas and Wright, 2012). However, at present, the drivers of these events are not well understood and thus difficult to model with physiologically based gap-filling procedures.

Following EddyPro processing, local despike and friction velocity filters were applied to the gas fluxes (Shoemaker et al., 2015d, e, f). The local despike filter removed half-hour fluxes that fell outside 3 standard deviations of the fluxes within a moving 7-day window. Friction velocity is an indicator of time periods when turbulent wind conditions are well developed. Eddy covariance methods are appropriate for turbulent wind conditions. The $u^{*}$ threshold was selected based on plots of $u^{*}$ versus nighttime (21:00 to 04:00) NEE normalized by air temperature and vapor pressure deficit, as described by Aubinet et al. (2012, p. 147). NEE appeared to be considerably different as $u^{*}$ decreased approximately below 0.1 threshold. Roughly 25,17 and $21 \%$ of NEE values were removed by the $u^{*}$, local despike and unrealistic value filters at the Cypress Swamp, Dwarf Cypress and Pine Upland sites, respectively.

At the Pine Upland site, NEE contamination was possible due to fossil fuel combustion by generators and trucks supporting oil-drilling activities adjacent to the eddy covariance tower. Thus, all carbon fluxes were removed at Pine Upland when the wind direction was from the east of the tower $(15$ to $130^{\circ}$ ). This filter removed about $50 \%$ of the remaining NEE data, under the assumption the NEE fluxes were likely affected by drilling activities. East winds were evenly dis- 
Table 2. Instrumentation installed at the Dwarf Cypress, Cypress Swamp and Pine Upland flux stations.

\begin{tabular}{|c|c|c|c|c|c|}
\hline \multirow[b]{2}{*}{ Instrument } & \multirow[b]{2}{*}{ Model } & \multirow[b]{2}{*}{ Measurement } & \multicolumn{3}{|c|}{ Distance above or below land surface, in meters } \\
\hline & & & Dwarf Cypress & Pine Upland & Cypress Swamp \\
\hline Sonic anemometer & CSAT $^{\mathrm{a}}$, Gill Windmaster Pro ${ }^{\mathrm{b}}$ & Wind velocity and direction & 15.5 & 35.8 & 35.7 \\
\hline Gas analyzer & LI-7500A & Gas concentrations & 15.5 & 35.8 & 35.7 \\
\hline Methane analyzer & LI-7700 & Methane concentration & 15.5 & NA & NA \\
\hline Pressure transducer & CS450 & Water depth & -0.8 & -0.5 & -0.5 \\
\hline Air temperature & HMP-45C & Air temperature & 15.5 & 35.8 & 35.8 \\
\hline Relative humidity & HMP-45C & Relative humidity & 15.5 & 35.8 & 35.8 \\
\hline Net radiometer & NR-Lite & Net radiation & 13.2 & 33.7 & 33.9 \\
\hline Soil heat flux & REB & Soil heat flux & -0.2 & -0.2 & -0.2 \\
\hline Soil temperature & $107 \mathrm{~L}$ & Soil temperature & -0.2 & -0.2 & -0.2 \\
\hline
\end{tabular}

${ }^{a}$ CSAT deployed at the Dwarf Cypress and Pine Upland sites. ${ }^{\text {b }}$ Gill Windmaster Pro deployed at the Cypress Swamp site.

tributed over the day $\left(145^{\circ}\right.$ mean wind direction) and night ( $167^{\circ}$ mean wind direction). Winds originated from the east mostly during the winter (October to December) as regionalscale cold fronts moved southward with winds blowing over peninsular Florida from the Atlantic Ocean towards the Gulf of Mexico. Nevertheless, over 10000 NEE fluxes remained for trend identification and gap filling after the contamination filter at the Pine Upland site. Seasonal trends were apparent, and diurnal NEE variations were resolvable into surrogates for respiration and photosynthesis, as described below.

Missing $30 \mathrm{~min}$ fluxes (NEE, LE, H) were gap-filled using a lookup table approach (Table 3) documented in Reichstein et al. (2005). The lookup table replaces missing fluxes with available fluxes collected during similar meteorological conditions (net radiation within $50 \mathrm{~W} \mathrm{~m}^{-2}$, air temperature within $2.5^{\circ} \mathrm{C}$ and vapor pressure deficit within 5.0 Pa). Gapfilled fluxes are grouped into "Filling Quality A, B, and C". To briefly summarize, "Filling Quality A" fills gaps based on the availability of various combinations of NEE, net radiation, air temperature and vapor pressure deficit data that meet similarity requirements within a $1 \mathrm{~h}$ to 14 -day gap-centered window. "Filling Quality B" fills gaps based on the availability of NEE, net radiation, air temperature and vapor pressure deficit data that meet similarity requirements within a 1- to 140-day gap-centered window. "Filling Quality C" fills gaps based on averages of available NEE data surrounding the gap. Reichstein et al. (2005) contains further details regarding this gap-filling algorithm.

Positive NEE during the night was assumed to represent ecosystem respiration (RE). RE was weakly correlated with quantities such as air temperature $\left(R^{2}=0.01\right.$ and 0.03 for linear and exponential regression at Cypress Swamp, for example); thus, a statistical model was used for predicting RE during the day. Daytime RE predictions were needed for gross ecosystem exchange (GEE) estimates. The statistical model randomly estimated values for daytime RE within 1 standard deviation of the mean RE over 1 day. For example, if $20 \mathrm{RE}$ (+NEE) values were available within a $24 \mathrm{~h}$ pe- riod, the mean and standard deviation of RE was computed using 20 available values. Subsequently, 28 daytime RE values were randomly predicted from a range that was 1 standard deviation from the mean. Assuming that daytime and nighttime respiration statistics are equal could be a source of error in our results. The identification of an alternative for the RE statistical model was precluded by weak correlations between respiration and ancillary variables such as air temperature.

Methane emissions $\left(F_{\mathrm{CH}_{4}}\right)$ at the Dwarf Cypress site were most problematic in terms of missing $30 \mathrm{~min}$ data. About $80 \%$ of the $F_{\mathrm{CH}_{4}}$ time series was missing, mostly due to the poor signal strength of the methane analyzer (signal strength filter < 10). Furthermore, spikes in methane fluxes were removed when the signal strength indicator (RSSI) changed by \pm 10 between half-hourly time periods. Missing $F_{\mathrm{CH}_{4}}$ fluxes were distributed evenly over day and night. Sub-daily gap filling with the Reichstein et al. (2005) lookup table and empirical regression models was confounded by weak correlations with explanatory data, the greatest being $R^{2}=0.11$ with barometric pressure. Correlations were similarly weak when isolating methane emissions between 22:00 and 14:00; specifically, the greatest correlation $\left(R^{2}=0.12\right)$ occurred with vapor pressure deficit. Given weak sub-daily correlations, over 6000 molar methane fluxes were averaged by day and upscaled to 357 molar fluxes of $F_{\mathrm{CH}_{4}}$ at daily resolution.

Seasonally, missing daily $F_{\mathrm{CH}_{4}}$ molar fluxes were more prevalent from December 2012 to May 2013, October 2013 to January 2014, April 2014 to May 2014, and in November 2014. Due to the seasonality of missing data, a molar flux model was constructed (daily resolution) as a power function of continuous variables that explained seasonality in methane emission, specifically, air temperature and flooding at the Dwarf Cypress site. The methane model was expressed as:

$F_{\mathrm{CH}_{4}}=R e^{\left(\mathrm{BT}_{a}\left(1+e^{a+b(\text { stage })}\right)\right)}$,

where $T_{\mathrm{a}}$ and stage were mean daily air temperature (Celsius) and water distance above (+) or below (-) land surface 
Table 3. Gap-filling results for fluxes based on the lookup table approach by Reichstein et al. (2005).

\begin{tabular}{lrrr}
\hline Cypress Swamp & $H^{\mathrm{a}}$ & $\mathrm{LE}^{2}$ & NEE \\
\hline Filling Quality A & 8239 & 10591 & 11506 \\
Filling Quality B & 32 & 34 & 31 \\
Filling Quality C & 9 & 9 & 13 \\
Total gap-filled & 8280 & 10634 & 11550 \\
Total fluxes & 34848 & 34848 & 34848 \\
Percent rejected & 24 & 31 & 33 \\
\hline Dwarf Cypress & $H$ & LE & NEE \\
\hline Filling Quality A & 6830 & 8365 & 9828 \\
Filling Quality B & 389 & 398 & 393 \\
Filling Quality C & 70 & 70 & 74 \\
Total gap-filled & 7289 & 8833 & 10295 \\
Total fluxes & 35328 & 35328 & 35328 \\
Percent rejected & 21 & 25 & 29 \\
\hline Pine Upland & $H$ & LE & NEE \\
\hline Filling Quality A & 9001 & 9997 & 23554 \\
Filling Quality B & 138 & 139 & 174 \\
Filling Quality C & 243 & 242 & 393 \\
Total gap-filled & 9382 & 10378 & 24121 \\
Total fluxes & 35424 & 35424 & 35424 \\
Percent rejected & 26 & 29 & 68 \\
\hline
\end{tabular}

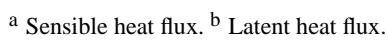

(meters), respectively. Least-squares regression defined values of $R=0.008628, B=0.04, a=-3.8$ and $b=2.7$ that minimized sum of squared differences between observed and computed $F_{\mathrm{CH}_{4}}$ molar fluxes (Fig. 3). The $F_{\mathrm{CH}_{4}}$ model explained about $40 \%$ of the variability in mean daily $F_{\mathrm{CH}_{4}}$ fluxes.

Daily NEE, RE and $F_{\mathrm{CH}_{4}}$ were converted from molar to mass units. Gross daily mass transfer of $\mathrm{C}$ from the atmosphere to the ecosystem (GEE, $\mathrm{g} \mathrm{C} \mathrm{m}^{-2} \mathrm{~d}^{-1}$ ) was calculated as the sum of $-\mathrm{NEE}$ and RE during the day. Daily GEE, NEE, RE and $F_{\mathrm{CH}_{4}}$ were summed to generate monthly and annual $\mathrm{C}$ exchange totals. An upper bound for uncertainty in these totals was approximated using a root mean square error propagating method (Topping, 1972). To summarize, possible sources of error included random uncertainty (Finkelstein and Sims, 2001) and gap-filling error. Gap-filling error was approximated using the standard error for \pm NEE gap filling by Reichstein et al. (2005). Standard errors were computed by creating artificial gaps $(1,5,10$ and $20 \%$ removal) in observed NEE and predicting fluxes during the artificial gaps with the lookup table.

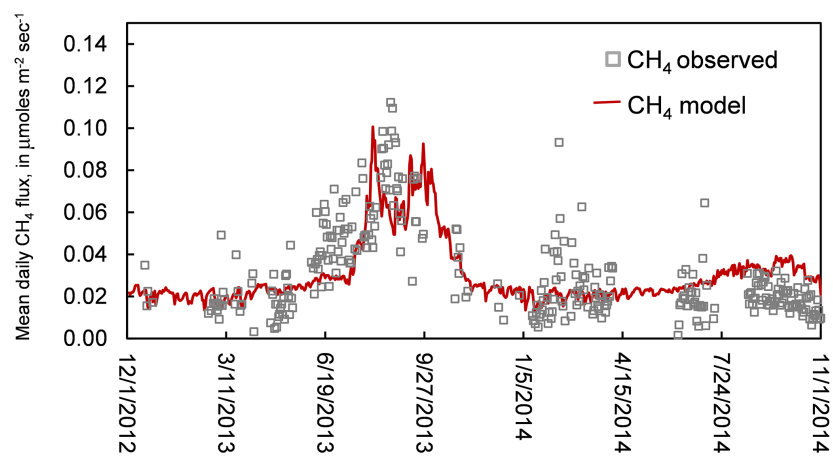

Figure 3. Observed and computed mean daily molar methane $\left(\mathrm{CH}_{4}\right)$ flux at the Dwarf Cypress site.

The maximum standard error of the artificial gap scenarios was used to approximate an upper bound for uncertainty, as follows:

$U_{-\mathrm{NEE}, \mathrm{RE}}=\sqrt{\sum_{t=0}^{\text {month }}\left(U_{r}^{2}+\mathrm{SE}_{\max }^{2}\right)}$,

where $U_{-\mathrm{NEE}, \mathrm{RE}}$ were monthly uncertainties in NEE or RE in $\mathrm{g} \mathrm{C} \mathrm{m}^{-2}$ per month, $U_{\mathrm{r}}$ was random uncertainty (Finkelstein and Sims, 2001) in $\mathrm{gC} \mathrm{m}^{-2} \mathrm{~s}^{-1}$ and $\mathrm{SE}_{\max }$ was the maximum standard error of the artificial gap scenarios $(20 \%$ removal scenario, equal to $2.2,1.1$ and $2.0 \mathrm{~g} \mathrm{C} \mathrm{m}^{-2} \mathrm{~s}^{-1}$ for Cypress Swamp, Dwarf Cypress and Pine Upland, respectively). Uncertainty in monthly GEE was the sum of uncertainty for NEE and RE. Uncertainty in $F_{\mathrm{CH}_{4}}$ was estimated with Eq. (3) using random uncertainty estimates (Finkelstein and Sims, 2001) for the methane fluxes and the standard error (equal to $0.017 \mathrm{~g} \mathrm{C} \mathrm{m}^{-2} \mathrm{~d}^{-1}$ ) of the methane flux model (Eq. 2).

\section{Results and discussion}

\subsection{Seasonality in rainfall, temperature, water levels and energy fluxes}

The subtropics of south Florida are characterized by distinct wet and dry seasons driven by changes in solar insolation, air temperature, humidity and rainfall. Rainfall and photosynthesis are greatest in the hot and humid spring and summer months from about May to October. The end of October generally marks the end of the wet season (and hurricane season). Wetland water levels and surface energy fluxes are tightly coupled to seasonality in heat and humidity. Cold fronts are especially remarkable within surface energy budgets, as dry cold air passes over relatively warm soil and surface water, creating large variations in both stored-heat energy and turbulent fluxes of heat and water vapor (Shoemaker et al., 2011). 


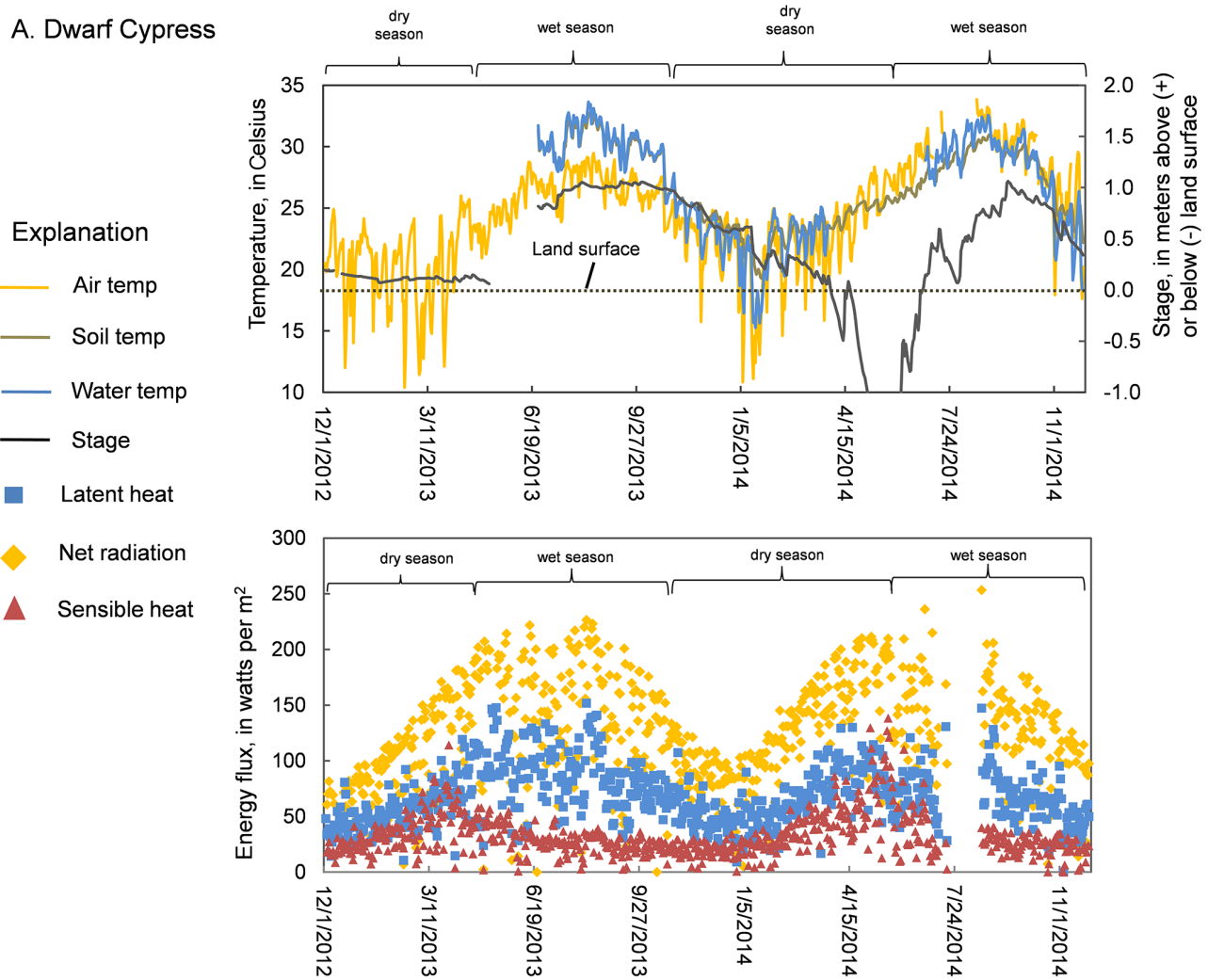

Figure 4.

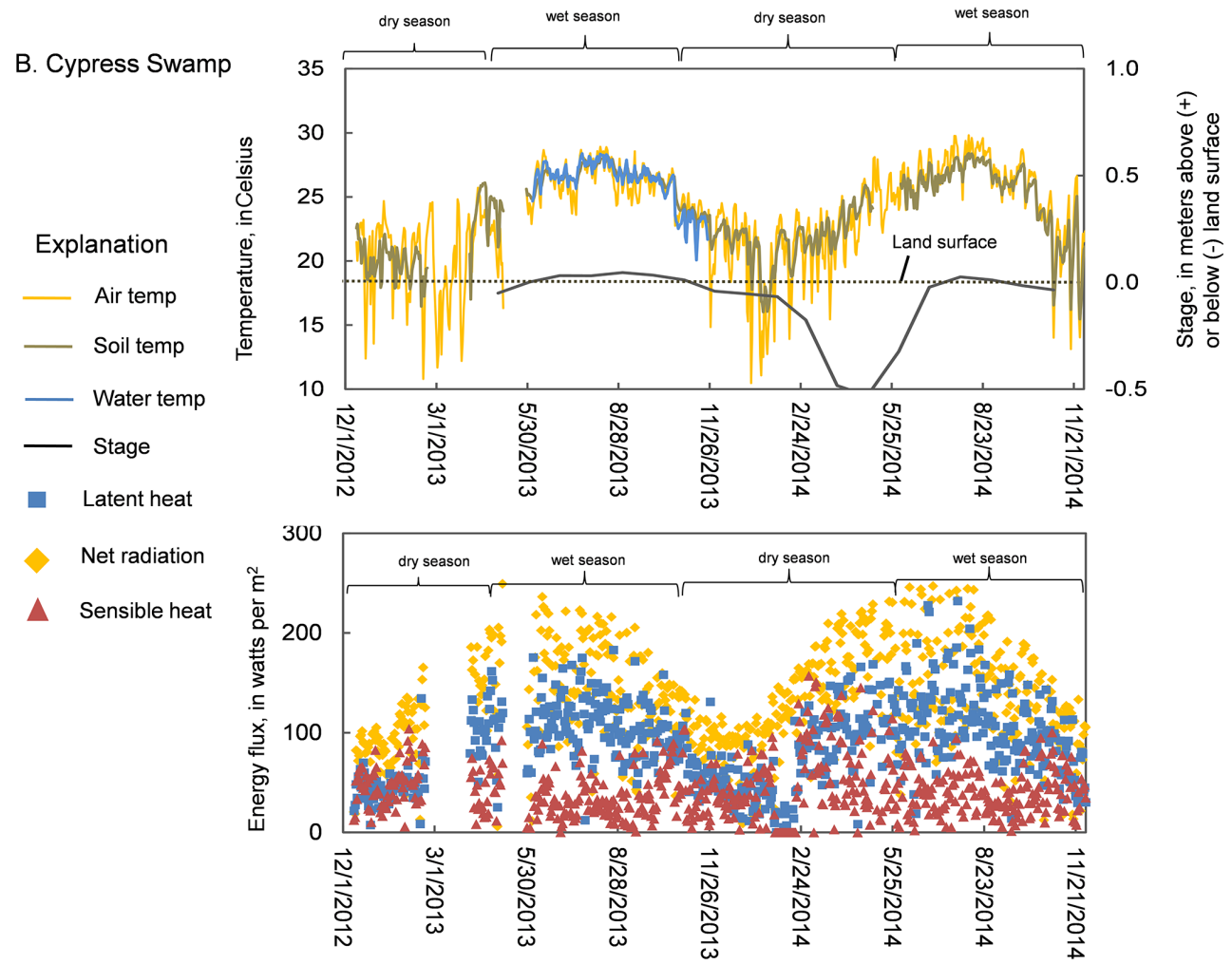

Figure 4. 


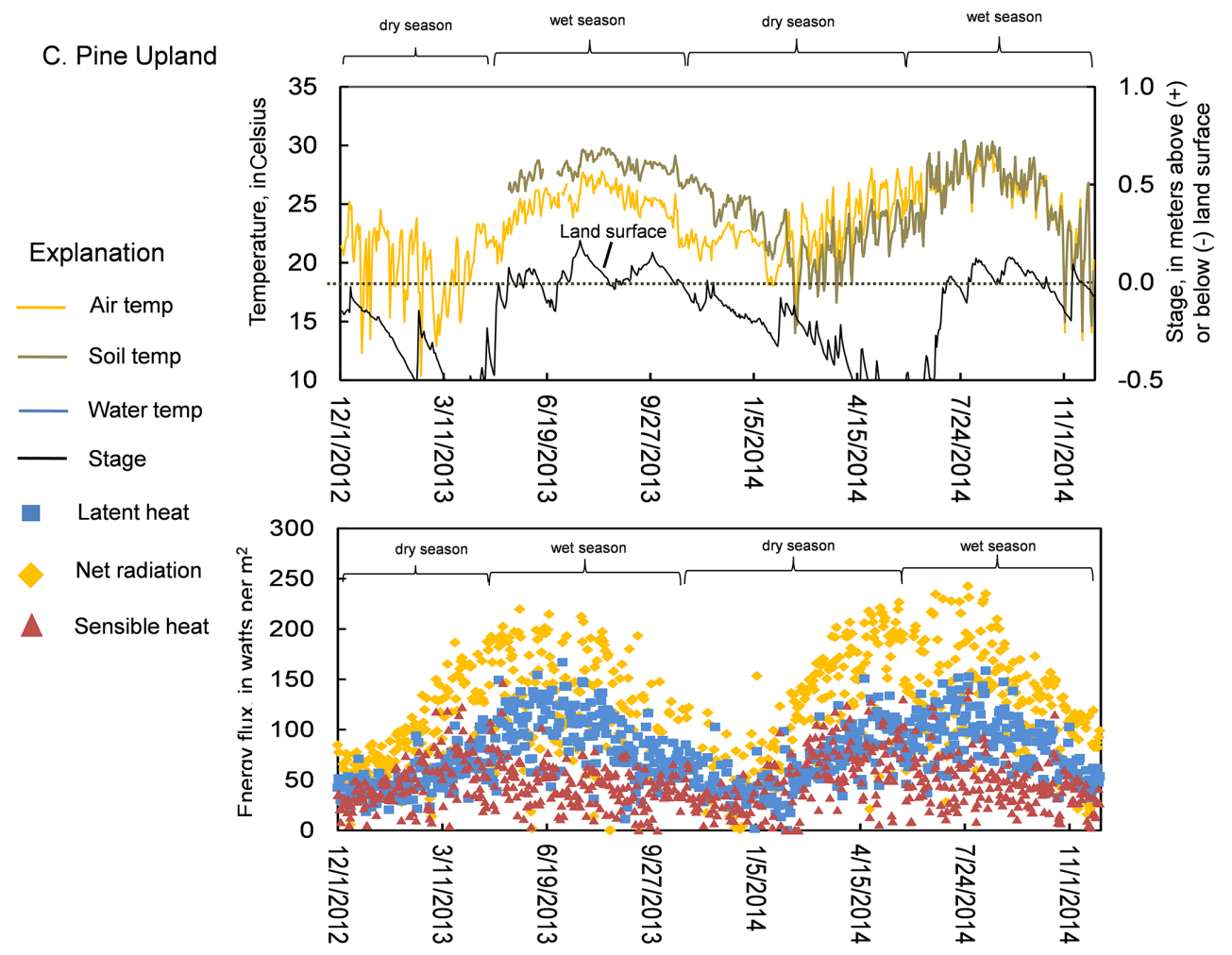

Figure 4. Mean daily temperature and surface energy fluxes. Dates are given in the format month/day/year.

During this study, air temperatures at all three sites (Fig. $4 \mathrm{a}-\mathrm{c}$ ) were seasonally lowest (ranging from 15 to $25^{\circ} \mathrm{C}$ ) during December through March and as low as $12^{\circ} \mathrm{C}$ for several days during the passage of cold fronts in the winter. Cold fronts typically lasted 5 days or less. During April and May, air temperatures rose above $25^{\circ} \mathrm{C}$ and were less variable as hot and humid air masses dominated the subtropical region. By late May, air temperatures were consistently 25 to $30^{\circ} \mathrm{C}$ and remained within this range until the onset of the dry season in mid- to late October. Water and soil temperatures (measured $0.15 \mathrm{~m}$ below land surface) were nearly identical (absolute differences $<1{ }^{\circ} \mathrm{C}$ ) but were 1 to $5^{\circ} \mathrm{C}$ higher than air temperature during the passage of cold fronts (Fig. 4). Land surface served as a heat reservoir during cold fronts, and water and soil temperatures seldom fell below $15^{\circ} \mathrm{C}$. Cold fronts also increased vapor pressure deficits due to cold, dry air moving rapidly over a relatively wet and warm landscape.

Seasonality was observed in water levels at each site (Fig. 4a, b and c) in response to rainfall duration and intensity. Water levels were lower in the winter and early spring due to reduced rainfall at the end of the dry season (i.e., November to May). Water levels rose in response to rainfall at the end of April 2013 and May 2014, reaching $\sim 1 \mathrm{~m}$ above land surface during July through October at the Dwarf Cypress site. In contrast, water levels declined by as much as $1.0 \mathrm{~m}$ below land surface during the spring dry season from March to May 2014 (Fig. 4a, b and c), creating an opportunity for enhanced soil respiration. Water levels remained below land surface until rainfall in June 2014 eventually flooded each site.

Surface energy fluxes reflected the seasonality in air temperature and rainfall (Fig. 4a, b, c). Mean daily net radiation ranged from about 50 to over $200 \mathrm{~W} \mathrm{~m}^{-2}$ and was greatest in the summer months of June, July and August 2013 and 2014. Net radiation was least from November to February when incoming solar radiation was seasonally smallest. Net radiation was the primary driver of available energy and latent heat flux (Fig. 4a, b, c), the energy equivalent of evapotranspiration (ET). Mean daily latent heat fluxes ranged from about 0 to over $150 \mathrm{~W} \mathrm{~m}^{-2}$ and were greatest in the summer months of June, July and August 2013 and 2014 at the Cypress Swamp site. Latent heat fluxes were lowest from November to February when incoming solar radiation was seasonally lowest, and less water was available for evaporation. During these cooler and drier periods, transpiration was also limited by a lower physiological activity of trees, especially of the deciduous cypress trees (Fig. 2b) during fall-winter leaf drop (Fig. 4b). Surface inundation combined with more incoming solar radiation resulted in more energy partitioned as latent versus sensible heat during May to November. Also, cypress leaves were notably greener during this period, suggesting increased physiological activity and seasonally higher transpiration rates. 
Table 4. Monthly and annual $\mathrm{C}$ and methane fluxes.

\begin{tabular}{|c|c|c|c|c|c|c|c|c|c|c|}
\hline \multirow[b]{2}{*}{ Month } & \multicolumn{3}{|c|}{ Cypress Swamp } & \multicolumn{4}{|c|}{ Dwarf Cypress } & \multicolumn{3}{|c|}{ Pine Upland } \\
\hline & NEE* & $\mathrm{RE}^{*}$ & GEE* & NEE* & $\mathrm{RE}^{*}$ & GEE* & $\mathrm{CH}_{4}^{*}$ & NEE* & $\mathrm{RE}^{*}$ & GEE* $^{*}$ \\
\hline December 2012 & $-19 \pm 4$ & $31 \pm 2$ & $49 \pm 6$ & $-18 \pm 1$ & $27 \pm 1$ & $45 \pm 3$ & $0.6 \pm 0.003$ & $-52 \pm 3$ & $45 \pm 6$ & $96 \pm 10$ \\
\hline January 2013 & $-30 \pm 5$ & $51 \pm 2$ & $81 \pm 8$ & $-25 \pm 1$ & $35 \pm 3$ & $59 \pm 5$ & $0.6 \pm 0.004$ & $-54 \pm 4$ & $63 \pm 6$ & $117 \pm 10$ \\
\hline February 2013 & $-31 \pm 4$ & $57 \pm 2$ & $87 \pm 6$ & $-22 \pm 4$ & $43 \pm 3$ & $65 \pm 7$ & $0.5 \pm 0.003$ & $-40 \pm 4$ & $60 \pm 11$ & $100 \pm 15$ \\
\hline March 2013 & $-75 \pm 3$ & $83 \pm 2$ & $157 \pm 5$ & $-27 \pm 2$ & $39 \pm 2$ & $66 \pm 5$ & $0.5 \pm 0.002$ & $-59 \pm 4$ & $69 \pm 8$ & $127 \pm 12$ \\
\hline April 2013 & $-98 \pm 5$ & $117 \pm 3$ & $215 \pm 8$ & $-50 \pm 3$ & $45 \pm 4$ & $94 \pm 7$ & $0.6 \pm 0.003$ & $-62 \pm 5$ & $82 \pm 14$ & $143 \pm 20$ \\
\hline May 2013 & $-123 \pm 5$ & $99 \pm 3$ & $221 \pm 9$ & $-61 \pm 3$ & $45 \pm 3$ & $106 \pm 6$ & $0.6 \pm 0.006$ & $-89 \pm 5$ & $64 \pm 13$ & $152 \pm 19$ \\
\hline June 2013 & $-131 \pm 5$ & $68 \pm 3$ & $199 \pm 8$ & $-58 \pm 5$ & $43 \pm 3$ & $101 \pm 8$ & $1.1 \pm 0.005$ & $-88 \pm 6$ & $56 \pm 20$ & $143 \pm 26$ \\
\hline July 2013 & $-107 \pm 5$ & $51 \pm 3$ & $157 \pm 9$ & $-59 \pm 3$ & $43 \pm 1$ & $102 \pm 4$ & $1.5 \pm 0.006$ & $-103 \pm 6$ & $54 \pm 22$ & $157 \pm 29$ \\
\hline August 2013 & $-96 \pm 6$ & $53 \pm 4$ & $149 \pm 10$ & $-45 \pm 3$ & $37 \pm 3$ & $82 \pm 7$ & $2.3 \pm 0.011$ & $-82 \pm 4$ & $41 \pm 15$ & $122 \pm 19$ \\
\hline September 2013 & $-67 \pm 6$ & $61 \pm 3$ & $128 \pm 10$ & $-32 \pm 4$ & $36 \pm 4$ & $68 \pm 8$ & $2 \pm 0.004$ & $-45 \pm 4$ & $58 \pm 11$ & $103 \pm 16$ \\
\hline October 2013 & $-51 \pm 4$ & $55 \pm 2$ & $106 \pm 7$ & $-27 \pm 2$ & $28 \pm 1$ & $55 \pm 4$ & $1.7 \pm 0.004$ & $-29 \pm 3$ & $44 \pm 9$ & $73 \pm 13$ \\
\hline November 2013 & $-42 \pm 5$ & $61 \pm 3$ & $103 \pm 15$ & $-24 \pm 2$ & $32 \pm 3$ & $55 \pm 6$ & $0.8 \pm 0.004$ & $-11 \pm 4$ & $39 \pm 12$ & $50 \pm 17$ \\
\hline Annual total & $-865 \pm 61$ & $794 \pm 37$ & $1658 \pm 106$ & $-443 \pm 39$ & $461 \pm 36$ & $903 \pm 76$ & $13 \pm 0.06$ & $-708 \pm 58$ & $681 \pm 153$ & $1389 \pm 211$ \\
\hline December 2013 & $-29 \pm 4$ & $53 \pm 2$ & $82 \pm 7$ & $-23 \pm 2$ & $31 \pm 2$ & $54 \pm 4$ & $0.7 \pm 0.004$ & $-12 \pm 4$ & $34 \pm 10$ & $45 \pm 14$ \\
\hline January 2014 & $-30 \pm 5$ & $51 \pm 3$ & $80 \pm 8$ & $-19 \pm 2$ & $32 \pm 3$ & $51 \pm 5$ & $0.5 \pm 0.002$ & $-28 \pm 4$ & $45 \pm 9$ & $73 \pm 13$ \\
\hline February 2014 & $-29 \pm 5$ & $55 \pm 3$ & $84 \pm 9$ & $-22 \pm 1$ & $28 \pm 2$ & $49 \pm 4$ & $0.8 \pm 0.002$ & $-64 \pm 4$ & $42 \pm 9$ & $105 \pm 13$ \\
\hline March 2014 & $-64 \pm 5$ & $84 \pm 3$ & $147 \pm 8$ & $-34 \pm 2$ & $40 \pm 2$ & $73 \pm 5$ & $0.6 \pm 0.002$ & $-55 \pm 4$ & $76 \pm 16$ & $130 \pm 21$ \\
\hline April 2014 & $-119 \pm 5$ & $127 \pm 3$ & $245 \pm 9$ & $-46 \pm 3$ & $55 \pm 3$ & $100 \pm 6$ & $0.6 \pm 0.004$ & $-73 \pm 4$ & $88 \pm 12$ & $160 \pm 17$ \\
\hline May 2014 & $-136 \pm 5$ & $141 \pm 3$ & $276 \pm 9$ & $-39 \pm 3$ & $58 \pm 3$ & $97 \pm 6$ & $0.6 \pm 0.004$ & $-64 \pm 5$ & $121 \pm 13$ & $185 \pm 18$ \\
\hline June 2014 & $-125 \pm 1$ & $101 \pm 0$ & $226 \pm 2$ & $-48 \pm 2$ & $53 \pm 2$ & $101 \pm 4$ & $0.6 \pm 0.001$ & $-64 \pm 1$ & $134 \pm 5$ & $198 \pm 6$ \\
\hline July 2014 & $-131 \pm 4$ & $68 \pm 3$ & $198 \pm 8$ & $-45 \pm 2$ & $41 \pm 2$ & $86 \pm 4$ & $0.6 \pm 0$ & $-89 \pm 5$ & $83 \pm 20$ & $172 \pm 26$ \\
\hline August 2014 & $-125 \pm 5$ & $67 \pm 3$ & $191 \pm 9$ & $-34 \pm 2$ & $41 \pm 1$ & $75 \pm 4$ & $0.5 \pm 0.009$ & $-75 \pm 5$ & $52 \pm 17$ & $126 \pm 23$ \\
\hline September 2014 & $-81 \pm 5$ & $68 \pm 3$ & $148 \pm 8$ & $-32 \pm 4$ & $39 \pm 4$ & $71 \pm 8$ & $0.4 \pm 0.006$ & $-77 \pm 6$ & $64 \pm 19$ & $140 \pm 25$ \\
\hline October 2014 & $-62 \pm 5$ & $67 \pm 3$ & $129 \pm 8$ & $-24 \pm 2$ & $32 \pm 2$ & $56 \pm 4$ & $0.4 \pm 0.007$ & $-51 \pm 3$ & $48 \pm 4$ & $98 \pm 8$ \\
\hline November 2014 & $-32 \pm 4$ & $68 \pm 2$ & $99 \pm 7$ & $-16 \pm 3$ & $26 \pm 3$ & $41 \pm 6$ & $0.6 \pm 0.001$ & $-27 \pm 3$ & $46 \pm 11$ & $72 \pm 14$ \\
\hline Annual total & $-956 \pm 60$ & $954 \pm 37$ & $1909 \pm 97$ & $-377 \pm 33$ & $481 \pm 33$ & $858 \pm 66$ & $7 \pm 0.04$ & $-673 \pm 54$ & $837 \pm 150$ & $1509 \pm 205$ \\
\hline
\end{tabular}

* Units are $\mathrm{g} \mathrm{C}^{-2}$ month $^{-1}$ or $\mathrm{C} \mathrm{m}^{-2} \mathrm{yr}^{-1}$ for net ecosystem exchange (NEE), respiration (RE), gross exchange (GEE) and methane production $\left(\mathrm{CH}_{4}\right)$.

\subsection{Carbon exchange between the atmosphere and forested wetlands}

All three sites were generally sinks of atmospheric carbon dioxide $\left(\mathrm{CO}_{2}\right)$ on daily, monthly (Fig. 5a, b, c) and annual timescales (Table 4). The sink strength of $\mathrm{CO}_{2}$ at each site, as evidenced by NEE, was reduced during the fall and winter of 2012, 2013 and 2014 (Table 4, Fig. 5). Seasonality in daily NEE was least at Dwarf Cypress, with NEE ranging from -1.0 to $-2 \mathrm{~g} \mathrm{C} \mathrm{m}^{-2} \mathrm{~d}^{-1}$ in the winter and summer, respectively. Seasonality in NEE was more extreme in $\mathrm{Cy}$ press Swamp and Pine Upland, with rates ranging from -1 to $-5 \mathrm{~g} \mathrm{C} \mathrm{m}^{-2} \mathrm{~d}^{-1}$ in the winter and summer, respectively. Lack of forested vegetation at Dwarf Cypress likely explains the dampened seasonality in $\mathrm{C}$ fluxes. Furthermore, pine trees grow and maintain leaves all year (evergreen trees), which likely explains dampened seasonality in NEE at Pine Upland relative to Cypress Swamp.

The Moderate-resolution Imaging Spectroradiometer (MODIS) enhanced vegetation index (EVI) served as a useful qualitative surrogate for seasonal terrestrial photosynthetic activity and canopy structural variations (Fig. 5), as reported for some other studies (Huete et al., 2002). EVI over a tall mangrove forest, for example, varied seasonally between 0.35 and 0.55 and decreased to $\sim 0.2$ following defoliation after hurricane Wilma (Barr et al., 2013). Likewise, EVI over evergreen forest (Xiao et al., 2004) varied seasonally between 0.25 during the winter and 0.5 during the summer growing season. EVI data were obtained from the MOD13A1 product of MODIS (EOS; http://modis.gsfc.nasa.gov/). Sixteen-day composite EVI values for the pixels corresponding to each station and the eight adjacent pixels were extracted for comparison with monthly $\mathrm{C}$ fluxes (Fig. 5). This nine-pixel domain approximately corresponds with the measurement footprint of each flux station.

Seasonal patterns in NEE and GEE were consistent with changes in EVI (Fig. 5a, b, c), most notably at the Cypress Swamp site. Increases in EVI from 0.25 to 0.35 corresponded with growth of cypress leaves on relatively tall (18 to $21 \mathrm{~m}$ ) and densely spaced cypress trees (Fig. 2) beginning in about March to April. Cypress leaves discontinued growing in August to September and turned brown in October, eventually falling into the sawgrass and hardwood understory. This lack of photosynthetic activity corresponded with changes in EVI of 0.4 to 0.2 in the summer and in the winter (Fig. 5b), respectively, of 2013 and 2014 at the Cypress Swamp flux station.

Gross atmosphere-ecosystem C exchange (GEE) provides a first approximation of gross ecosystem productivity (GEP) 


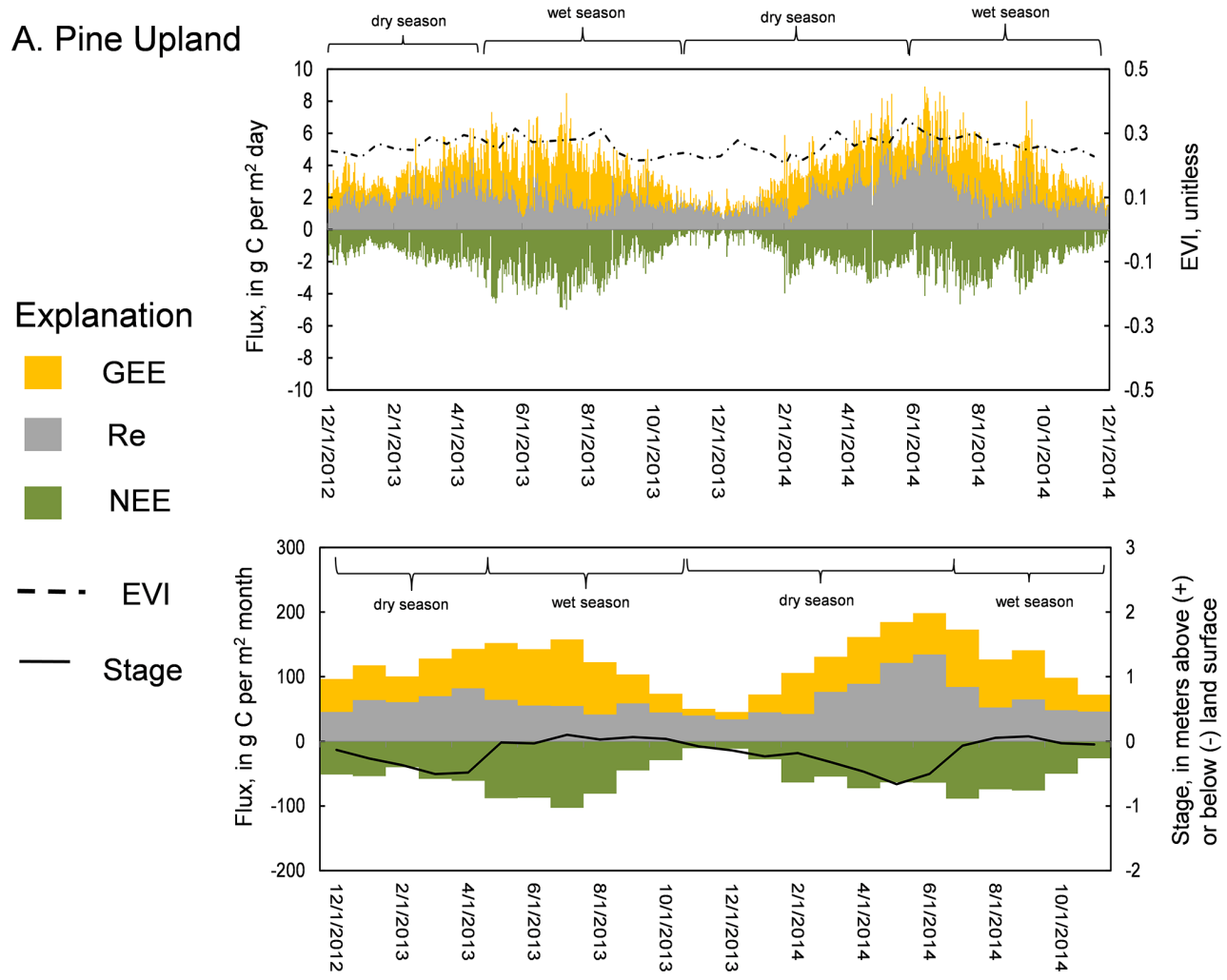

Figure 5.

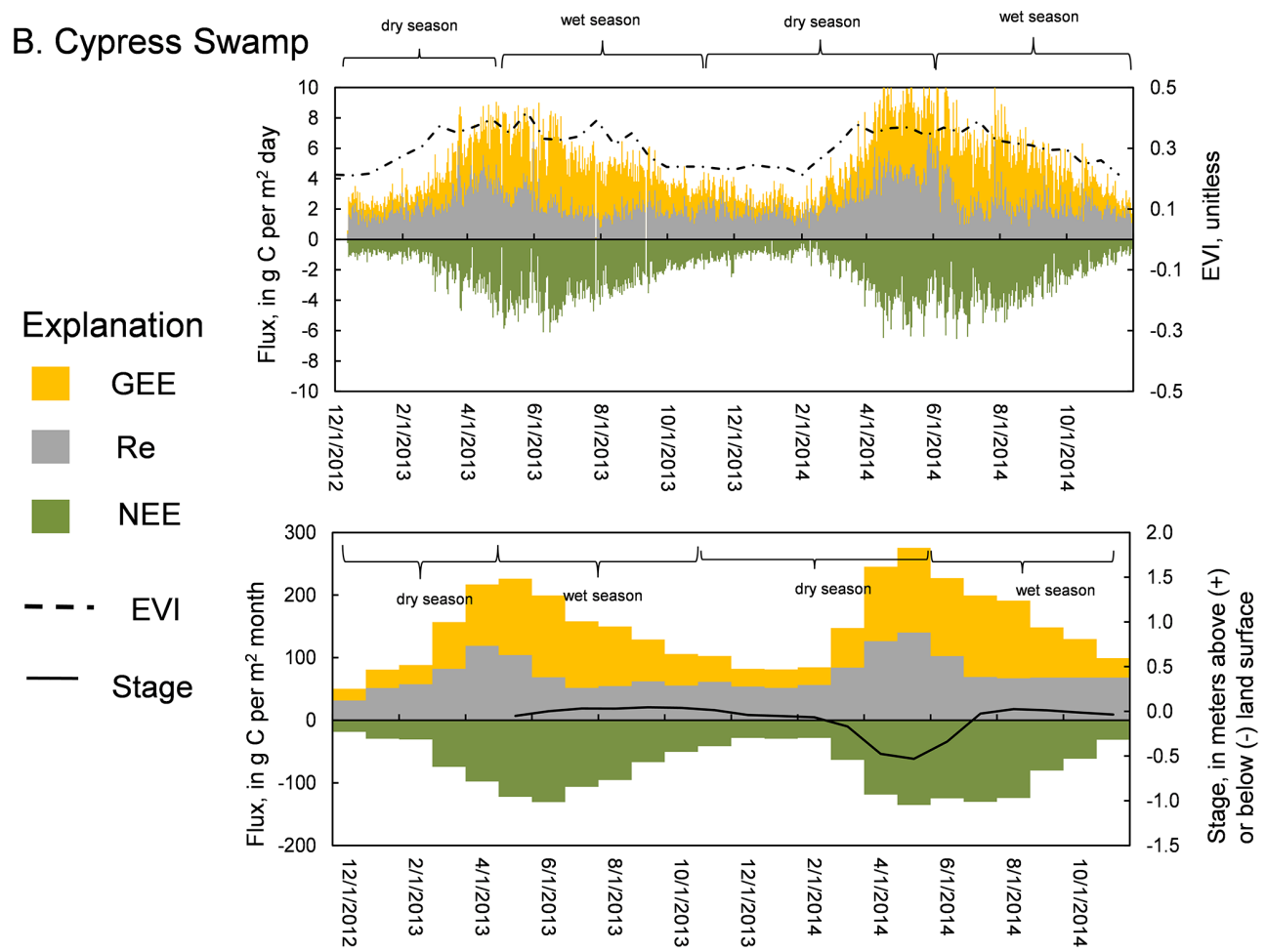

Figure 5. 


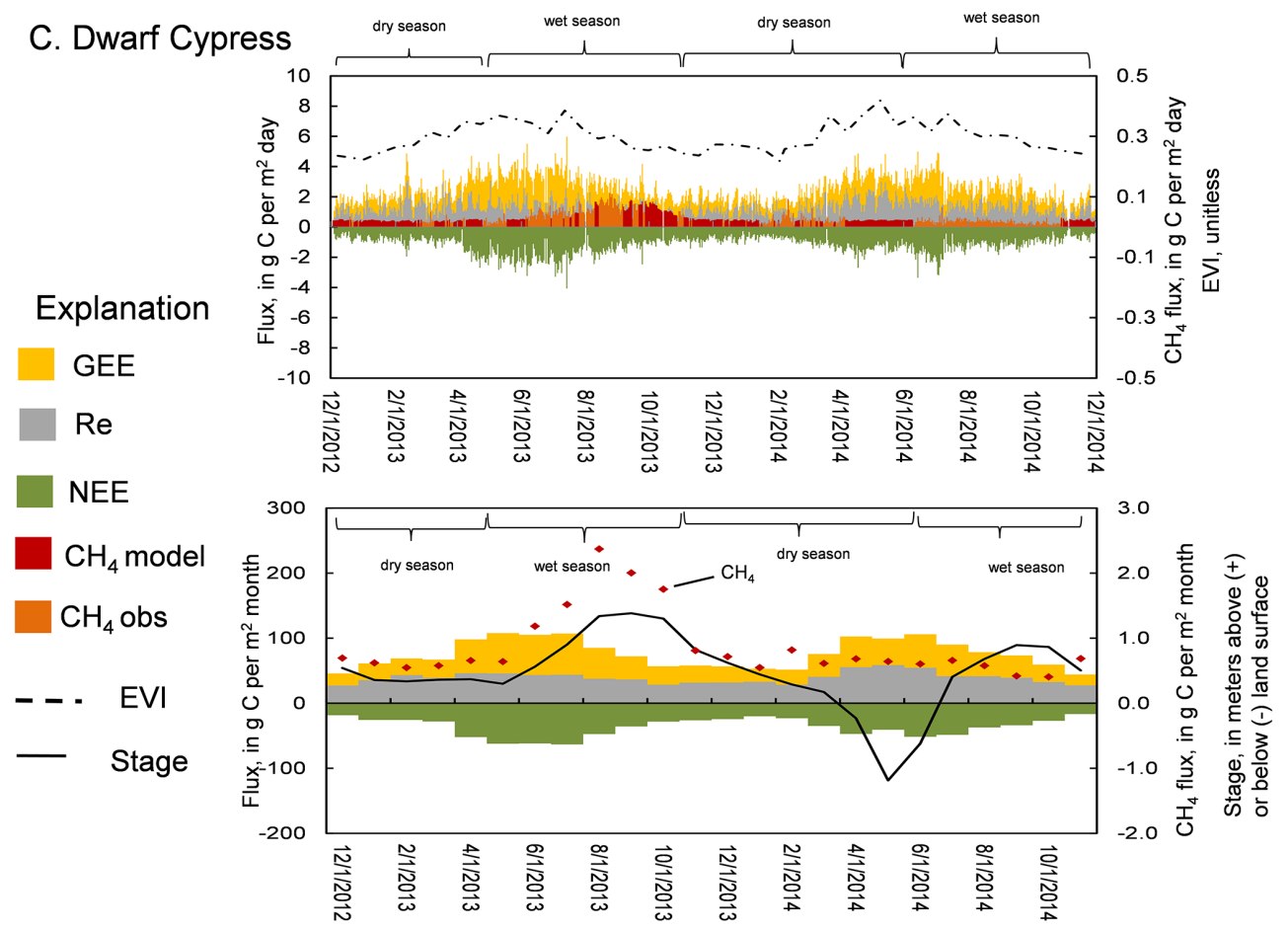

Figure 5. Daily and monthly C fluxes, stage and EVI at the (a) Pine Upland, (b) Cypress Swamp and (c) Dwarf Cypress sites. Dates are given in the format month/day/year.

or the accumulation of $\mathrm{C}$ in the plant canopy. Growth and senescence of cypress leaves was most evident in monthly GEE (Fig. 5, Table 4) at the Cypress Swamp site, where rates increased from about $100 \mathrm{~g} \mathrm{C} \mathrm{m}^{-2}$ in February 2013 to over $200 \mathrm{~g} \mathrm{C} \mathrm{m}^{-2}$ in April 2013 (a $116 \%$ increase). Likewise, GEE increased from about $100 \mathrm{~g} \mathrm{C} \mathrm{m}^{-2}$ in February 2014 to about $300 \mathrm{~g} \mathrm{C} \mathrm{m}^{-2}$ in June 2014 (a $200 \%$ increase). At the Dwarf Cypress site, seasonal changes in GEE were more moderate; the February to April 2013 increase was from about 60 to $100 \mathrm{~g} \mathrm{C} \mathrm{m}^{-2}$ (a $66 \%$ increase). Foliage change at the Cypress Swamp site likely contributed to a larger fraction of the site's change in photosynthetic $\mathrm{CO}_{2}$ uptake than at the Dwarf Cypress site, which consists of a sparse cypress canopy (Fig. 2) during the height of the growing season (i.e., April to September).

A key water and ecosystem management issue in south Florida, and globally, is the preservation of organic soils within wetlands (Hohner and Dreschel, 2015) to (1) support ecosystem services and (2) maintain or grow topography. Growing topography via $\mathrm{C}$ accumulation in these coastal forested wetlands could partly offset sea-level rise. Inundation suppressed respiration most remarkably at Cypress Swamp and Pine Upland (Fig. 5a, b). RE doubled from about 60 to $120 \mathrm{~g} \mathrm{C} \mathrm{m}^{-2}$ from February to May 2014, when water levels were below land surface at Cypress Swamp (Fig. 5b). Enhanced RE was also observed from March 2014 to July 2014 at Pine Upland (Fig. 5a), when water levels were below land surface. Enhanced RE was likely due to heterotrophic soil respiration supplementing autotrophic respiration when water levels were below land surface for extended periods of time. These results suggest hydroperiods could be managed for the maintenance of organic soils and peat accretion in these subtropical cypress- and pine-forested wetlands.

\subsection{Links between $\mathrm{C}$ and water cycles}

Relationships between net ecosystem C exchange (NEE) and latent heat flux (LE) reflect an important link between water and $\mathrm{C}$ cycles (Fig. 6), that is, photosynthesis that releases water (transpiration) while storing C. $R^{2}$ between NEE and LE provides an indication of the relative magnitudes of transpiration and evaporation at each site. Stronger correlations between NEE and LE indicate increased transpiration relative to evaporation, as water is transpired during photosynthesis while the plant fixes C. In contrast, weaker correlations indicate a site with more open-water evaporation, where the source for ET is less related to photosynthesis and more related to evaporation from a water surface. Correlations between NEE and LE were 0.35, 0.36 and 0.19 (Fig. 6) at the Cypress Swamp, Pine Upland and Dwarf Cypress sites, respectively. These correlations indicate that transpiration is a larger portion of evapotranspiration at forested wetlands with larger and more densely spaced cypress and pine trees. Closed or partially closed forested canopies reduced the penetration of solar radiation to water surfaces, creating low- 


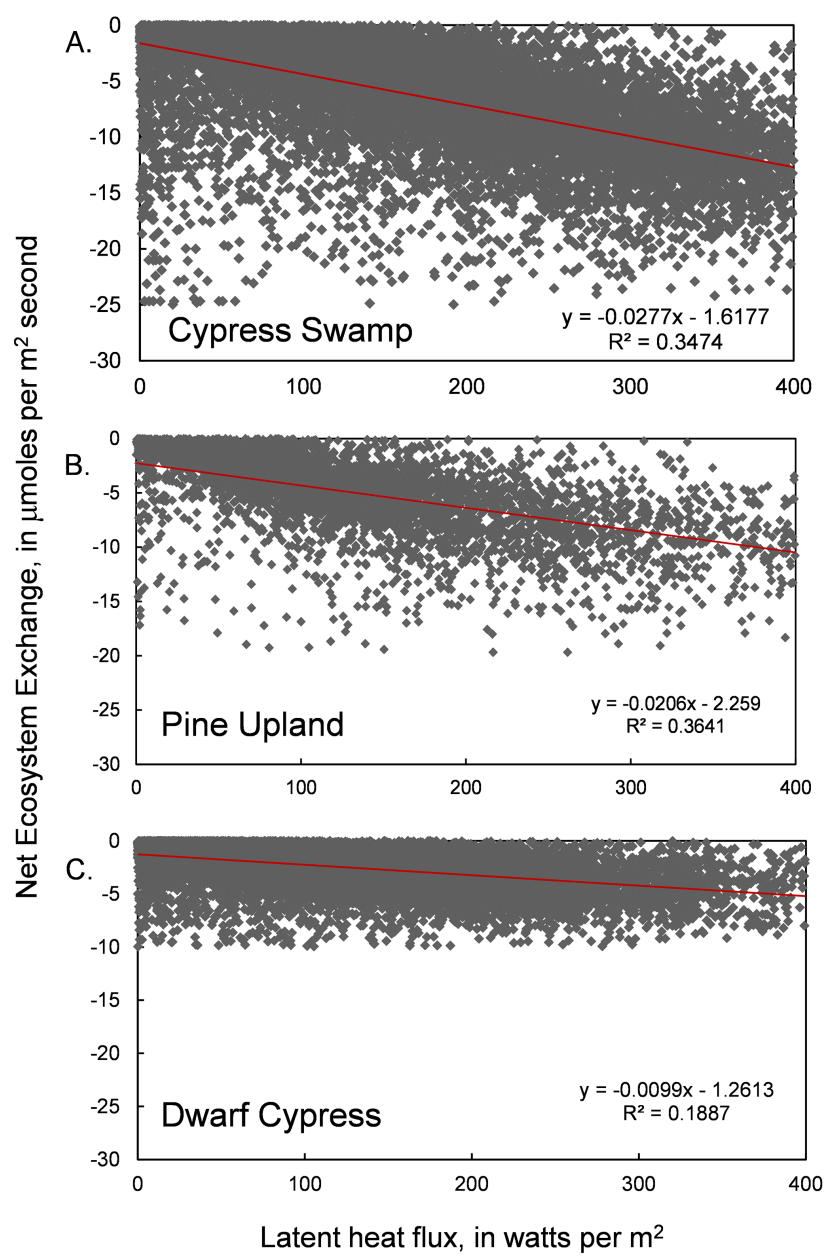

Figure 6. Relations between latent heat flux and net ecosystem exchange.

ered lapse rates between the water surface and canopy crown (Barr et al., 2012), and they added resistance to evaporation. Collectively, these results indicate that a redistribution of plant communities toward more open-water ecosystems (such as sparse sawgrass) could result in less $\mathrm{C}$ uptake and greater evaporative losses. Prior studies of $\mathrm{C}$ accumulation further support this generalization; for example, NEE rates were greater over mangrove systems (Barr et al., 2010, 2012) than over sawgrass wetlands (Schedlbauer et al., 2010). Furthermore, previous ET studies (German, 2000) indicate that ET losses are greater over wetlands with sparse sawgrass and open-water conditions.

Coupling between water and $\mathrm{C}$ cycles was examined via water-use efficiencies (WUEs) (Table 5) computed as the ratio of annual NEE to ET. As such, WUEs are the net mass or moles of $\mathrm{C}$ transferred to the ecosystem per millimeter or mole of water vapor. Computing WUE with NEE accounts for the loss of $\mathrm{C}$ through $R e$. The Cypress Swamp and Pine Upland sites were most efficient at using water to store $\mathrm{C}$, with WUE equal to about $1.0 \mathrm{~g} \mathrm{C}$ per mmET (1.0 to 1.4 moles $\mathrm{CO}_{2}$ per mole of ET). About $0.5 \mathrm{~g} \mathrm{C}$ uptake occurs per millimeter of ET $\left(0.7\right.$ moles $\mathrm{CO}_{2}$ per mole of ET) at the Dwarf Cypress site. Apparently, wetlands with more openwater surface (Fig. 2) are less efficient than forested wetlands at converting water use into net and gross $\mathrm{C}$ uptake. This conclusion is likely to be true both regionally and perhaps globally and, thus, may have implications for the global C cycle.

\subsection{Methane emission}

Methane is produced by anaerobic bacteria decomposing organic matter in the soil or in surface water. Methane can be oxidized during transport from the soil or surface water into the atmosphere. Transport to the atmosphere may occur through (1) roots and stems of vascular plants (Wang and Han, 2005; Morrissey et al., 1993; Kim and Verma, 1998), (2) ebullition as gas bubbles from anaerobic soils (Comas and Wright, 2012) and (3) diffusion through the soil and surface water (Van Huissteden et al., 2006; Christensen et al., 2003a, b). Methane emission is enhanced as anaerobic bacteria become more active at higher temperatures (Simpson et al., 1995).

At the Dwarf Cypress site, methane emission increased with increasing air temperature and water level in the summer months from June to September 2013 (Fig. 5c). In contrast, methane emission was suppressed from April to June 2014 due to dry conditions and perhaps the memory of dry conditions from July to September 2014. Anaerobic bacteria may take some time to reestablish following dry conditions. This reestablishment or "memory" of dry conditions would reduce methane emission despite warm conditions and flooding from July to September 2014.

Methane emission peaked at different times in the summer of 2013 compared to GEE at the Dwarf Cypress site (Fig. 5c). GEE peaked with photosynthesis in July 2013 whereas methane emission peaked in August 2013. This time lag indicates that the processes governing $\mathrm{C}$ exchange and methane emissions are quite different, with GEE controlled by the photosynthesis of cypress leaves and sawgrass, which grow vigorously from March to April and discontinue growth from August to September. In contrast, methane emission is driven by the anaerobic decomposition of organic matter with subsequent oxidation through the soil and surface water. Organic decomposition was enhanced in August 2013 by flooding and relatively warm air, soil and surface water.

Although methane emission is important in terms of global warming potential (GWP), it appears to be immaterial in C budgets that alter or "grow" land surface topography. C released from methane emission was relatively small (averaging about $10 \mathrm{~g} \mathrm{Cyr}^{-1}$ ) compared to NEE (about $-500 \mathrm{~g} \mathrm{C}^{2}$ per $\mathrm{m}^{2} \mathrm{yr}^{-1}$, Table 4). Thus, $\mathrm{C}$ cycling studies that address changes in peat accumulation may not benefit from monitoring methane fluxes. However, about $14 \mathrm{~g} \mathrm{CH}_{4}$ emission per year is roughly equivalent to $350 \mathrm{~g} \mathrm{CO}_{2}$, assuming that the 
Table 5. ET, NEE and WUE at the flux stations.

\begin{tabular}{lrr|rr|rr}
\hline Site & \multicolumn{2}{c|}{ ET $^{1}$} & \multicolumn{2}{c|}{ NEE $^{2}$} & \multicolumn{2}{c}{ WUE $^{3}$} \\
\hline Pine Upland & $1050\left(\mathrm{yr}^{4}\right)$ & $1070\left(\mathrm{yr}^{5}\right)$ & $-700\left(\mathrm{yr}^{4}\right)$ & $-700\left(\mathrm{yr} 2^{5}\right)$ & $0.7 / 1.0\left(\mathrm{yr} 1^{4}\right)$ & $0.7 / 1.0\left(\mathrm{yr} 2^{5}\right)$ \\
Dwarf Cypress & $970\left(\mathrm{yr}^{4}\right)$ & $900\left(\mathrm{yr}^{5}\right)^{5}$ & $-450\left(\mathrm{yr}^{4}\right)$ & $-400\left(\mathrm{yr}^{5}\right)$ & $0.5 / 0.7\left(\mathrm{yr}^{4}\right)^{4}$ & $0.4 / 0.7\left(\mathrm{yr}^{5}\right)$ \\
Cypress Swamp & $1000\left(\mathrm{yr}^{4}\right)$ & $1100\left(\mathrm{yr}^{5}\right)$ & $-900\left(\mathrm{yr}^{4}\right)$ & $-1000\left(\mathrm{yr}^{5}\right)$ & $0.9 / 1.4\left(\mathrm{yr}^{4}\right)$ & $0.9 / 1.4\left(\mathrm{yr}^{5}\right)$ \\
\hline
\end{tabular}

${ }^{1}$ Units are millimeters per year. ${ }^{2}$ Units are $\mathrm{g} \mathrm{Cyr}^{-1} .{ }^{3}$ Units are $\mathrm{g} \mathrm{C}$ per millimeter $\mathrm{ET}$ or (/) moles $\mathrm{CO}_{2}$ per mole ET. ${ }^{4}$ yr1 from 1 December 2012 to 30 November 2013. ${ }^{5} \mathrm{yr} 2$ from 1 December 2013 to 30 November 2014.

GWP of $\mathrm{CH}_{4}$ is 25 times greater than $\mathrm{CO}_{2}$ (over a 100-year period, IPCC, 2007). We recognize that GWP multipliers are controversial due to assumptions such as instantaneous $\mathrm{CH}_{4}$ and $\mathrm{CO}_{2}$ release and the timescale dependence of the radiative forcing contributions (Mitsch et al., 2013). Careful use of GWP multipliers for wetlands is suggested.

\subsection{Comparison of $\mathrm{C}$ uptake with previous studies}

A comparison of our results with NEE from selected previous studies (Schedlbauer et al., 2010; Jimenez et al., 2012; Barr et al., 2010; Botkin et al., 1970; Jones et al., 2014) reveals substantial spatial and temporal heterogeneity in $\mathrm{C}$ uptake over geologic time and among different ecosystems (Table 6). Subtropical forested wetlands exchange more C than temperate forests (Botkin et al., 1970; Sjogersten et al., 2014). A study assessing $C$ exchange on a geologic timescale (Jones et al., 2014) also concluded that long-term rates of C uptake in the Everglades are higher than in northern latitudes and in some cases rival $\mathrm{C}$ uptake in tropical peatlands, such as Indonesia. Mangrove ecosystems may serve as an upper limit for subtropical C uptake, with an NEE of about $-1170 \mathrm{~g} \mathrm{C}$ per $\mathrm{m}^{2} \mathrm{yr}^{-1}$ (Barr et al., 2010).

Sparse sawgrass wetlands in the Everglades, such as Taylor and Shark River sloughs, are relatively minor atmospheric $\mathrm{C}$ sources or sinks, with NEE ranging from -50 (Taylor Slough) to +45 (Shark River Slough) g C per $\mathrm{m}^{2} \mathrm{yr}^{-1}$ (Table 5). Jones et al. (2014) also concluded that sloughs sequester the least amount of $\mathrm{C}$ in their study of $\mathrm{C}$ accumulation over geologic timescales. Given the $\mathrm{C}$ released from methane emissions ( $10 \mathrm{~g} \mathrm{C}_{\text {per }} \mathrm{yr}^{-1}$, Table 4$)$, as measured at Dwarf Cypress (Fig. 5c), sparse sawgrass wetlands may generally be atmospheric $\mathrm{C}$ sources on monthly and annual timescales, with a questionable value as local, regional and global C sinks.

\section{Conclusions}

Atmospheric-ecosystem carbon dioxide exchange, methane emission and latent and sensible heat fluxes were estimated with eddy covariance methods for subtropical forested cypress and pine wetlands for 2 years. Seasonality in solar insolation, air temperature, plant physiological activity, rainfall and water levels created seasonality in $\mathrm{C}$ exchange rates and surface energy fluxes. Links between water and $\mathrm{C}$ fluxes were also revealed, such as photosynthetic water-use efficiencies.

Each forested wetland was an atmospheric $\mathrm{C}$ sink on monthly and annual timescales. Atmospheric $\mathrm{C}$ uptake (NEE) was greatest at Cypress Swamp ( -900 to $-1000 \mathrm{~g} \mathrm{C}$ per $\left.\mathrm{m}^{2} \mathrm{yr}^{-1}\right)$, moderate at Pine Upland ( -650 to $-700 \mathrm{~g} \mathrm{C}$ per $\left.\mathrm{m}^{2} \mathrm{yr}^{-1}\right)$ and least at Dwarf Cypress $(-400$ to $-450 \mathrm{~g} \mathrm{C}$ per $\mathrm{m}^{2} \mathrm{yr}^{-1}$ ). The size (about $20 \mathrm{~m}$ ) and number of cypress trees enhanced C uptake at Cypress Swamp, and seasonality in $\mathrm{C}$ uptake rates was enhanced by the growth of cypress leaves in early April and the decay of cypress leaves in late October, as confirmed by changes in the satellite-derived EVI. Changes in EVI (from 0.25 in the dry season to 0.4 in the wet season) served as a useful surrogate for monthly and seasonal changes in net and gross ecosystem $\mathrm{C}$ exchange.

Respiration was enhanced when water levels dropped below land surface within these cypress- and pine-forested wetlands. Increases in respiration were likely due to heterotrophic soil respiration supplementing autotrophic respiration. These results highlight the importance of flooding and hydroperiod management for maintaining organic soils and peat accretion within subtropical forested wetlands, a key water and ecosystem management issue in south Florida and globally.

Links between water and $\mathrm{C}$ cycles were examined via (1) WUEs expressed as the ratio of annual NEE to ET and (2) correlations between NEE and LE. Computing WUE with NEE accounts for the loss of $\mathrm{C}$ through respiration. The Cypress Swamp and Pine Upland sites were most efficient at using water to store $\mathrm{C}$, with WUE equal to about $1.0 \mathrm{~g} \mathrm{C}$ per millimeter ET. About $0.5 \mathrm{~g} \mathrm{C}$ was stored in the ecosystem per millimeter of ET at the Dwarf Cypress site. These results indicate that wetlands with more open-water surface are less efficient at using water to store $\mathrm{C}$ than forested wetlands. This pattern is likely to be true both regionally and perhaps globally, and thus, may have implications for the global $\mathrm{C}$ cycle.

Correlations between NEE and LE reflected photosynthesis, which released water as transpiration while storing C. The strength of the NEE and LE correlation provided an indication of the relative magnitudes of transpiration and evaporation at each site. Transpiration was a large proportion of evapotranspiration at the Cypress Swamp and Pine Upland sites, as indicated by correlations of $0.34,0.36$ and 0.18 for the Cypress Swamp, Pine Upland and Dwarf Cypress 
Table 6. Comparison of annual totals of NEE for different studies.

\begin{tabular}{lrll}
\hline Ecosystem & NEE$^{*}$ & Climate & Reference \\
\hline Taylor Slough (short sawgrass) & -50 & Subtropics & Schedlbauer (2010) \\
Shark River Slough (short sawgrass) & 45 & Subtropics & Jimenez (2012) \\
Mangrove & -1170 & Subtropics & Barr (2010) \\
Cypress Swamp & -900 to -1000 & Subtropics & This study \\
Dwarf Cypress & -400 to -500 & Subtropics & This study \\
Pine Upland & -750 to -800 & Subtropics & This study \\
White Oak & -296 & Temperate & Botkin (1070) \\
Scarlet Oak & -274 & Temperate & Botkin (1070) \\
Pitch Pine & -124 & Temperate & Botkin (1070) \\
Everglades & -100 to $>-200$ & Subtropics & Jones et al. (2014) \\
\hline
\end{tabular}

${ }^{*}$ Units are $\mathrm{g} C$ per $\mathrm{m}^{2} \mathrm{yr}^{-1}$

sites, respectively. These results indicate that a redistribution of plant communities toward more open-water ecosystems could create less $C$ uptake and greater evaporative losses.

Methane emission at Dwarf Cypress was considerable in terms of global warming potential but immaterial in $\mathrm{C}$ budgets that build and maintain land-surface topography. Approximately $14 \mathrm{gCH}_{4}$ was released into the atmosphere, roughly equivalent to $350 \mathrm{~g} \mathrm{CO}_{2}$, assuming that the global warming potential of $\mathrm{CH}_{4}$ is about 25 times greater than $\mathrm{CO}_{2}$. Methane emission, however, did not reverse carbon accumulation for the topography at Dwarf Cypress, as the $\mathrm{C}$ released from methane emission (about $10 \mathrm{~g} \mathrm{C}_{\text {per }} \mathrm{yr}^{-1}$ ) was relatively small compared to NEE $\left(-500 \mathrm{~g} \mathrm{C}_{\text {per }} \mathrm{m}^{2} \mathrm{yr}^{-1}\right)$. These results indicate that, while methane monitoring is needed when assessing the global warming potential of wetlands, $\mathrm{C}$ cycling studies that address changes in topography and peat accumulation may not benefit from monitoring methane fluxes.

Acknowledgements. This study was funded, in part, by the US Geological Survey (USGS) Greater Everglades Priority Ecosystems Science (GEEES). Nick Aumen is acknowledged for helpful conversations about the Everglades during project meetings and fieldwork in BCNP. Michael J. Duever provided detailed vegetation descriptions and guidance during site selection. Steve Krupa and Cynthia Gefvert from the South Florida Water Management District funded tower construction. USGS peer reviews by Lisamarie Windham-Myers, Dave Sumner and Kim Haag improved the quality of the manuscript. Biogeoscience peer reviews by Ankur Desai and an anonymous referee also greatly improved the manuscript. Any use of trade, firm or product names is for descriptive purposes only and does not imply endorsement by the US Government. The data used to create this manuscript is openly available to the public at http://sofia.usgs.gov/exchange/carbonexchange/.

Edited by: T. Keenan

\section{References}

Aubinet, M., Vesala, T., and Papale, D.: Eddy Covariance: A Practical Guide to Measurement and Data Analysis, Springer, Dordrecht, Heidelberg, London, New York, 460 pp., 2012.

Baldocchi, D. D., Hicks, B. B., and Meyers, T. P.: Measuring biosphere-atmosphere exchanges of biologically related gases with micrometeorological methods, Ecology, 69, 1331-1340, 1988.

Barr, J. G., Engel, V. C., Fuentes, J. D., Zieman, J. C., O'Halloran, T. L., Smith III, T. J., and Anderson, G. H.: Controls on mangrove forest-atmosphere carbon dioxide exchanges in western Everglades National Park, J. Geophys. Res., 115, G02020, doi:10.1029/2009JG001186, 2010.

Barr, J. G., Engel, V., Smith, T. J., and Fuentes, J. D.: Hurricane disturbance and recovery of energy balance, $\mathrm{CO}_{2}$ fluxes and canopy structure in a mangrove forest of the Florida Everglades, Agr. Forest Meteorol., 153, 54-66, doi:10.1016/j.agrformet.2011.07.022, 2012.

Barr, J. G., Engel, V., Fuentes, J. D., Fuller, D. O., and Kwon, H.: Modeling light use efficiency in a subtropical mangrove forest equipped with $\mathrm{CO}_{2}$ eddy covariance, Biogeosciences, 10, 21452158, doi:10.5194/bg-10-2145-2013, 2013.

Botkin, D. B., Woodwell, G. M., and Tempel, N.: Forest productivity estimated from carbon dioxide uptake, Ecology, 51, 10571060, 1970.

Bridgham, S. D., Megonigal, J. P., Keller, J. K., Bliss, N. B., and Trettin, C.: The carbon balance of North American wetlands, Wetlands, 26, 889-916, 2006.

Campbell, G. S. and Norman, J. M.: An introduction to environmental biophysics,Springer, New York, p. 286, ISBN: 0-387-949372, 1998.

Chapin, F. S., Woodwell, G. M., Randerson, J. T., Rastetter, E. B., Lovett, G. M., Baldocchi, D. D., Clark, D. A., Harmon, M. E., Schimel, D. S., and Valentini, R.: Reconciling carbon- cycle concepts, terminology, and methods, Ecosystems, 9, 1041-1050, doi:10.1007/s10021-005-0105-7, 2006.

Christensen, T. R., Panikov, N., Mastepanov, M., Joabsson, A., Stewart, A., Oquist, M., Sommerkorn, M., Reynaud, S., and Svensson, B.: Biotic controls on $\mathrm{CO}_{2}$ and $\mathrm{CH}_{4}$ exchange in wetlands - a closed environment study, Biogeochemistry, 64, 337354, 2003a. 
Christensen, T. R., Ekberg, A., Strom, L., Mastepanov, M., Panikov, N., Mats, O., Svensson, B. H., Nykanen, H., Martikainen, P. J., and Oskarsson, H.: Factors controllinglarge scale variations in methane emissions from wetlands, Geophys. Res. Lett., 30, 1414, doi:10.1029/2002GL016848, 2003b.

Comas, X. and Wright W.: Heterogeneity of biogenic gas ebullition in subtropical peat soils is revealed using time-lapse cameras, Water Resour. Res., 48, W04601, doi:10.1029/2011WR011654, 2012.

Duever, M. J.: Southwest Florida Predevelopment Vegetation Map, Map Publication of the South Florida Water Management District, 2002.

Duever, M. J., Carlson, J. E., Meeder, J. F., Duever, L. C., Gunderson, L. H., Riopelle, L. A., Alexander, T. R., Myers, R. L., and Spangler, D. P.: The Big Cypress National Preserve, New York, National Audubon Society, 455 pp., 1986.

Dyer, A. J.: Measurements of evaporation and heat transfer in the lower atmosphere by an automatic eddy covariance technique, Q. J. Roy. Meteor. Soc., 87, 401-412, 1961.

Finkelstein, P. L. and Sims, P. F.: Sampling error in eddy correlation flux measurements, J. Geophys. Res., 106, 3503-3509, 2001.

German, E. R.: Regional evaluation of evapotranspiration in the Everglades: U.S. Geological Survey Water Resources Investigations Report 00-4217, 48p̃ p., 2000.

Hohner, S. M. and Dreschel, T. W.: Everglades peats: using historical and recent data to estimate predrainage and current volumes, masses and carbon contents, Mires and Peat, 16, 1-15, available at: http://www.mires-and-peat.net/, ISSN 1819-754X, 2015.

Huete, A., Didan, K., Miura, T., Rodriguez, E. P., Gao, X., and Ferreira, L. G.: Overview of the radiometric and biophysical performance of the MODIS vegetation indices, Remote Sens. Environ., 83, 195-213, 2002.

Jimenez, K. L., Starr, G., Staudhammer, C. L., Schedlbauer, J. L., Loescher, H. W., Malone, S. L., and Oberbauer, S. F.: Carbon dioxide exchange rates from short- and long-hydroperiod Everglades freshwater marsh, J. Geophys. Res., 117, G04009, doi:10.1029/2012JG002117, 2012.

Jones, M. C., Bernhardt, C. E., and Willard, D. A.: Late Holocene vegetation, climate and land-use impacts on carbon dynamics in the Florida Everglades, Quaternary Sci. Rev., 90, 90-105, 2014.

Kim, J. and Verma, S. B.: Diel variation in methane emission from a midlatitudeprairie wetland: significance of convective through flow in Phragmites australis, J. Geophys. Res., 103, 29-39, 1998.

McPherson, B. F.: Vegetation map of southern parts of subareas A and C, Big Cypress Swamp, Florida, U.S. Geological Survey Hydrologic Atlas HA-492, 1973.

Mitsch, W. J., Bernal, B., Nahlik, A. M., Mander, U., Zhang, L., Anderson, C. J., Jørgensen, S. E., Brix, H.: Wetlands, carbon, and climate change, Landscape Ecol., 28, 583-597, doi:10.1007/s10980-012-9758-8, 2013.

Morrissey, L. A., Zobel, D. B., and Livingston, G. P.: Significance of stomatal control on methane release from Carex-dominated wetlands, Chemosphere, 26, 339-355, 1993.

Parker, G. G., Ferguson, G. E., and Love, S. K.: Water resources of southeastern Florida, with special reference to the geology and ground water of the Miami area, U.S. Geol. Surv. Water Supply Pap., 1255, 965 pp., 1955.

Reichstein, M., Falge, E., Baldocchi, D., Papale, D., Aubinet, M., Berbigier, P., and Valentini, R.: On the separation of net ecosys- tem exchange into assimilation and ecosystem respiration: review and improved algorithm, Glob. Change Biol., 11, 14241439, 2005.

Schedlbauer, J., Oberbauer, S., Starr, G., and Jimenez, K. L.: Seasonal differences in the $\mathrm{CO}_{2}$ exchange of a short-hydroperiod Florida Everglades marsh, Agr. Forest Meteorol., 150, 994-1006, doi:10.1016/j.agrformet.2010.03.005, 2010.

Shoemaker, W. B. and Sumner, D. M.: Alternate corrections for estimating actual wetland evapotranspiration from potential evapotranspiration, Wetlands, 26, 528-543, 2006.

Shoemaker, W. B., Lopez, C. D., and Duever M.: Evapotranspiration over spatially extensive plant communities in the Big Cypress National Preserve, southern Florida, 2007-2010, U.S. Geological Survey Scientific Investigations Report 2011-5212, p. 46, 2011.

Shoemaker, W. B., Anderson, F., Barr, J. G., Graham, S. L., and Botkin, D. B.: Carbon exchange between the atmosphere and subtropical forested cypress and pine wetlands, U.S. Geological Survey, Data Set for the Dwarf Cypress site, doi:10.5066/F7ZG6Q94, 2015d.

Shoemaker, W. B., Anderson, F., Barr, J. G., Graham, S. L., and Botkin, D. B.: Carbon exchange between the atmosphere and subtropical forested cypress and pine wetlands, U.S. Geological Survey Data Set for the Cypress Swamp site, doi:10.5066/F73776RZ, 2015e.

Shoemaker, W. B., Anderson, F., Barr, J. G., Graham, S. L., and Botkin, D. B.: Carbon exchange between the atmosphere and subtropical forested cypress and pine wetlands, U.S. Geological Survey Data Set for the Pine Upland site, doi:10.5066/F7707ZG9, 2015f.

Simpson, I. J., Thurtell, G. W., Kidd, G. E., Lin, M., DemetriadesShah, T. H., Flitcroft, I. D., Kanemasu, E. T., Nie, D., Bronson, K. F., and Neue, H. U.: Tunable diode laser measurements of methane fluxes from an irrigated rice paddy field in the Philippines, J. Geophys. Res., 100, 7283-7290, 1995.

Sjögersten, S., Black, C. R., Evers, S., Hoyos-Santillan, J., Wright E. L., and Turner, B. L.: Tropical wetlands: a missing link in the global carbon cycle, Global Biochem. Cy., 28, 1371-1386, doi:10.1002/2014GB004844, 2014.

Tanner, B. D. and Greene, J. P.: Measurement of sensible heat and water vapor fluxes using eddy correlation methods, Final report prepared for U.S. Army Dugway Proving Grounds, Dugway, Utah, 1989.

Tanner, C. B. and Thurtell, G. W.: Anemoclinometer measurements of Reynolds stress and heat transport in then atmospheric surface layer, University of Wisconsin Technical Report ECOM-66G22-F, 82 pp., 1969.

Tanner, B. D., Swiatek, E., and Greene, J. P.: Density fluctuations and use of the krypton hygrometer in surface flux measurements: Management of irrigation and drainage systems: Irrigation and Drainage Division, American Society of Civil Engineers, 21-23 July 1993, Park City, Utah, 945-952, 1993.

Topping, J.: Errors of Observation and Their Treatment. 4th Ed, Chapman and Hall, London, UK, 1972.

Troxler, T. G., Gaiser, E., Barr, J., Fuentes, J. D., Jaffé, R., Childers, D. L., Collado-Vides, L., Rivera-Monroy, V. H., CastañedaMoya, E., Anderson, W., Chambers, R., Chen, M., CoronadoMolina, C., Davis, S. E., Engel, V., Fitz, C., Fourqurean, J., Frankovich, T., Kominoski, J., Madden, C., Malone, S. L., Ober- 
bauer, S. F., Olivas, P., Richards, J., Saunders, C., Schedlbauer, J., Scinto, L. J., Sklar, F., Smith, T., Smoak, J. M., Starr, G., Twilley, R. R., and Whelan, K.: Integrated carbon budget models for the Everglades terrestrial-coastal-oceanic gradient: Current status and needs for inter-site comparisons, Oceanography, 26, 98$107,2013$.

van Huissteden, J., van den Bos, R., and Alvarez, I. M.: Modelling the effect of watertable management on $\mathrm{CO}_{2}$ and $\mathrm{CH}_{4}$ fluxes from peat soils, Neth. J. Geosci. Geol. En Mijnbouw, 85, 3-18, 2006.

Wang, Z. P. and Han, X. G.: Diurnal variation in methane emissions in relationto plants and environmental variables in the Inner Mongolia marshes, Atmos. Environ., 39, 6295-6305, 2005.
Webb, E. K., Pearman, G. I., and Leuning, R.: Correction of flux measurements for density effects due to heat and water vapour transfer, Q. J. Roy. Meteor. Soc., 106, 85-100, 1980.

Whalen, S. C.: Biogeochemistry of methane exchange between natural wet-lands and the atmosphere, Environ. Eng. Sci. 22, 73-94, 2005.

Xiao, X., Hollinger, D., Aber, J. D., Goltz, M., Davidson, E., Zhang, Q., and Moore III, B.: Modeling gross primary production of temperate deciduous broadleaf forest using satellite images and climate data, Remote Sens. Environ., 91, 256-270, 2004. 